\title{
A family-level Tree of Life for bivalves based on a Sanger- sequencing approach
}

David J. Combosch a, Timothy M. Collins b, Emily A. Glover c, Daniel L. Graf d, Elizabeth M. Harper e, John M. Healyf, Gisele Y. Kawauchi a,g, Sarah Lemer a, Erin McIntyre a, Ellen E. Strong h, John D. Taylor c, John D. Zardus i, Paula M. Mikkelsen i, Gonzalo Giribet a,c,j*, Rüdiger Bieler j,*

a Museum of Comparative Zoology, Department of Organismic and Evolutionary Biology, Harvard University, 26 Oxford Street, Cambridge, Massachusetts 02138, USA

b Department of Biological Sciences, Florida International University, Miami, Florida 33199, USA

c Department of Life Sciences, The Natural History Museum, Cromwell Road, London SW7 5BD, $U K$

d Biology Department, University of Wisconsin-Stevens Point, 800 Reserve Street, Stevens Point, Wisconsin 54481, USA

e Department of Earth Sciences, University of Cambridge, Downing Street, Cambridge, CB2 $3 E Q, U K$

${ }^{\mathrm{f}}$ Queensland Museum, PO Box 3300, South Brisbane, Queensland 4101, Australia

g Zoology Department, Universidade Federal de Minas Gerais, Brazil

h Department of Invertebrate Zoology, National Museum of Natural History, Smithsonian Institution, PO Box 37012, MRC 163, Washington, DC 20013, USA

I Department of Biology, The Citadel, 171 Moultrie Street, Charleston, South Carolina 29409, USA

j Integrative Research Center, Field Museum of Natural History, 1400 South Lake Shore Drive, Chicago, Illinois 60605, USA

* Co-corresponding authors 


\section{ABSTRACT}

The systematics of the molluscan class Bivalvia are explored using a 5-gene Sanger-based approach including the largest taxon sampling to date, encompassing 219 ingroup species spanning 93 (or $82 \%$ ) of the 113 currently accepted bivalve families. This study was designed to populate the bivalve Tree of Life at the family level and to place many genera into a clear phylogenetic context, but also pointing to several major clades where taxonomic work is sorely needed. Despite not recovering monophyly of Bivalvia or Protobranchia-as in most previous Sanger-based approaches to bivalve phylogeny-our study provides increased resolution in many higher-level clades, and supports the monophyly of Autobranchia, Pteriomorphia, Heteroconchia, Palaeoheterodonta, Heterodonta, Archiheterodonta, Euheterodonta, Anomalodesmata, Imparidentia, and Neoheterodontei, in addition to many other lower clades. However, deep nodes within some of these clades, especially Pteriomorphia and Imparidentia, could not be resolved with confidence. In addition, many families are not supported, and several are supported as non-monophyletic, including Malletiidae, Nuculanidae, Yoldiidae, Malleidae, Pteriidae, Arcidae, Propeamussiidae, Iridinidae, Carditidae, Myochamidae, Lyonsiidae, Pandoridae, Montacutidae, Galeommatidae, Tellinidae, Semelidae, Psammobiidae, Donacidae, Mactridae, and Cyrenidae; Veneridae is paraphyletic with respect to Chamidae, although this result appears to be an artifact. The denser sampling however allowed testing specific placement of species, showing, for example, that the unusual Australian Plebidonax deltoides is not a member of Donacidae and instead nests within Psammobiidae, suggesting that major revision of Tellinoidea may be required. We also showed that Cleidothaerus is sister group to the cementing member of Myochamidae, suggesting that Cleidothaeridae may not be a valid family and that cementation in Cleidothaerus and Myochama may have had a single origin. These results highlight the need for an integrative approach including as many genera as possible, and that the monophyly and relationships of many families require detailed reassessment. NGS approaches may be able to resolve the most recalcitrant nodes in the near future. 


\section{Introduction}

After decades of intense work by anatomists, paleontologists, and molecular biologists (e.g., Newell and Boyd, 1978; Popham, 1979; Steiner and Müller, 1996; Waller, 1998; Carter et al., 2000; Cope, 2000; Giribet and Wheeler, 2002; Giribet and Distel, 2003), the systematics of bivalves is stabilizing and we are beginning to see a resolved 'phylogenetic backbone' for the group, a prerequisite for any meaningful discussion of evolutionary pattern and process (Bieler et al., 2013). Several recent landmark papers on relationships within the class as a whole include large-scale Sanger-based molecular studies (e.g., Sharma et al., 2012), mitogenomic analyses (e.g., Plazzi et al., 2013), and a combination of Sanger-based sequences with an extensive morphological data matrix using an exemplarbased approach (Bieler et al., 2014), as well as the first Illumina-based phylogenomic analysis (González et al., 2015). These studies have resolved key aspects of relationships within bivalves, and virtually all of them converge on the monophyly of Heteroconchia, Pteriomorphia, Heterodonta, Palaeoheterodonta, Archiheterodonta, Euheterodonta, Anomalodesmata, and Imparidentia. This is not the case for many mitogenomic studies (e.g., Doucet-Beaupré et al., 2010; Plazzi et al., 2011), as it has been shown that they fail to recover deep molluscan relationships at many levels (e.g., Bernt et al., 2013; Stöger and Schrödl, 2013; Schrödl and Stöger, 2014). Other issues, including the monophyly of Protobranchia (Sharma et al., 2013), the interrelationships of Pteriomorphia (Lemer et al., 2016), the relative branching of the three main heterodont clades (Palaeoheterodonta, Archiheterodonta, and Euheterodonta), and most notably, the internal relationships of Imparidentia (Taylor et al., 2007), have remained somewhat uncertain (e.g., see Bieler et al., 2014), or have been only recently resolved with strong support by using phylogenomic approaches on transcriptomic data (González et al., 2015; Lemer et al., 2016). In the case of González et al. (2015), however, sampling was limited compared to previous Sanger-based approaches that had analyzed 103 bivalve species, for a group with more than 100 recognized extant families (Bieler et al., 2010).

To maximize taxonomic representation at the family level, we here expand the molecular data set of Bieler et al. (2014), which incorporated 81 of the 108 extant familylevel lineages then recognized. Accepting that Sanger-based approaches with traditional markers can provide little additional contribution to the resolution of the deepest nodes of the bivalve tree, this provides the first opportunity to place the vast majority of bivalve families in a phylogenetic context for future studies of the systematics, biogeography, and 
ecology of Bivalvia. Our goal was to sample as many of the 113 currently recognized extant bivalve families as possible. Ninety-three of these families are included in the present study, often with more than one representative. Included samples span all 12 families of the Protobranchia, 21 of 23 Pteriomorphia families (missing: Cucullaeidae, Entoliidae); all seven Palaeoheterodonta families; and four of five nominal Archiheterodonta families [but Condylocardiidae is now considered to be nested within Carditidae after the analysis of Archiheterodonta by González and Giribet (2014), here confirmed, and the only supposed extant member of the otherwise extinct Cardiniidae, Tellidorella Berry, 1963, is now recognized as a member of Lucinidae (Taylor et al., 2011)], thus including all of the three currently accepted families. We also sampled 38 of 45 families within the Imparidentia (missing: Basterotiidae, Galatheavalvidae, Sportellidae, Anatinellidae, Cardiliidae, Neoleptonidae, Erodonidae); and eleven of 20 Anomalodesmata families (missing: Penicillidae ${ }^{1}$, Pholadomyidae, Parilimyidae, Halonymphidae, Protocuspidariidae, Cetoconchidae, Euciroidae, Lyonsiellidae, Spheniopsidae). We also included samples of Kelliidae and Montacutidae, groups that were subsumed under a broader concept of Lasaeidae by Bieler et al. (2010). Three nominal families that have been added to the extant bivalve fauna most recently could not be analyzed herein: the Parallelodontidae, previously considered extinct, but now accepted by Huber (2015); Cyclochlamydidae (Dijkstra and Maestrati, 2012); and Clistoconchidae (Morton, 2012).

\section{Materials and methods}

\subsection{Species, Samples, Sequences}

In total we analyzed 219 ingroup taxa representing 93 bivalve families, and 10 outgroup taxa, including 3 Polyplacophora, 1 Monoplacophora, 1 Scaphopoda, and 5 Gastropoda. All analyzed specimens, including collection and voucher identifiers, GenBank accession numbers, and sampling locations, are listed in Table 1. This analysis is part of a larger study on bivalve evolution and samples were derived from a variety of sources, but here we limit our sampling to the molecular data, as collecting internal anatomical characters has not kept the pace of collecting molecular data (see Bieler et al., 2014).

\footnotetext{
${ }^{1}$ Penicillidae is invalid because the molluscan name Penicillus is a junior homonym. However, the senior name in Polychaeta is not in use and the molluscan name might be salvageable under ICZN (1999) Art. 23.9
} 
Additional collection information can be obtained from the online database of the Museum of Comparative Zoology, MCZbase (http://mczbase.mcz.harvard.edu), from the database of the Field Museum of Natural History (http://emuweb.fieldmuseum.org/iz/invertebrates.php), and the website of the Bivalve Tree of Life Project (http://www.bivatol.org). Authorship and literature information for cited higher taxa can be found at MolluscaBase (http://www.molluscabase.org).

\subsection{Molecular methods}

Total genomic DNA was extracted using the DNeasy tissue kit from QIAGEN (Valencia, CA, USA), from muscle or mantle tissue for large specimens or the entire body of small specimens. Five molecular markers were PCR-amplified, sequenced, and analyzed here, including one nuclear protein-coding gene (histone H3), one mitochondrial proteincoding gene (COI), two nuclear ribosomal genes (complete $18 \mathrm{~S}$ rRNA and a $2.2 \mathrm{~kb}$ fragment of $28 \mathrm{~S}$ rRNA) and one mitochondrial ribosomal gene (16S rRNA), as detailed by Bieler et al. (2014).

Sequence data were visualized and edited in Sequencher 5.1 (Gene Codes Corporation, Ann Arbor, MI, USA) and GENEIOUS Pro 7.1.7 (Biomatters Limited, Auckland, New Zealand). Additional sequences were obtained from RNA-Seq datasets (mostly by González et al., 2015), as indicated in Table 1. Sequences were screened for contamination using BLAST searches (ncbi.nlm.nih.gov) and new sequences were deposited on GenBank under the accession codes listed in Table 1.

\subsection{Phylogenetic analyses}

Probabilistic analyses were conducted under Bayesian inference and maximum likelihood on the static alignments generated with MUSCLE 3.6 (Edgar, 2004) with default parameters as implemented in GENEIOUS. To remove loci of ambiguous homology, sequence alignments for each amplicon (9 in total; 3 each for $18 \mathrm{~S}$ and $28 \mathrm{~S}$ rRNA, and one for each other marker) were individually analyzed with GBlocks 0.91b (Castresana, 2000) under the following conditions: flanking positions present in at least $51 \%$ of all sequences (b2 $=51 \%$ instead of $85 \%$ ), the block size was decreased to 3 (-b4 = 3 instead of 10$)$ and gap positions were removed only if they were present in more than half the sequences $(-b=h$ instead of none). Alignment lengths pre- and post-GBlocks are listed in Table 2. Amplicon 
alignments were subsequently concatenated using SeqMatrix 1.7.8 (Vaidya et al., 2011). The best-fit model of sequence evolution was estimated with jModelTest (Darriba et al., 2012) under the Akaike information criterion (AIC). GTR $+\mathrm{I}+\Gamma$ was selected overall and for each locus except for histone $\mathrm{H} 3$ for which the best-fit model was TIM1+I+ $\Gamma$.

Maximum likelihood analyses of the individual genes and the concatenated data sets were conducted using RAxML 8.2.8 on XSEDE (Stamatakis, 2014) as implemented on the CIPRES web portal (Miller et al., 2010). A unique GTR model of sequence evolution was specified for each molecular marker with corrections for a discrete gamma distribution $(\Gamma)$ for site-rate heterogeneity (GTRGAMMA). Nodal support was estimated via the rapid bootstrap algorithm (1000 replicates) using the GTRCAT model (Stamatakis et al., 2008).

Bayesian inference analyses were carried out with MrBayes 3.2 (Ronquist et al., 2012) as implemented on the CIPRES web portal. Analyses were conducted with a unique model applied to each partition with gamma corrections and a proportion of invariable sites $($ GTR + I $+\Gamma)$. Convergence diagnostics were analyzed using Tracer 1.6 (Rambaut et al., 2014). MrBayes analyses started with random trees, default priors and five runs, each with 3 hot and 1 cold Markov chains. The runs were allowed to proceed until the average deviation of split frequencies reached $<0.01$ ( $\sim 12 \mathrm{M}$ generations). Phylogenetic trees were summarized as a $50 \%$ majority-rule consensus tree with a burn-in of $25 \%$ removed using sumt as implemented in MrBayes.

In addition, IQtree 1.3.10 (Minh et al., 2013; Nguyen et al., 2015) was used for maximum likelihood analyses including model selection for each partition. Five independent runs were conducted, each with 1000 ultrafast bootstrap replications (Minh et al., 2013), and we present the most likely tree (Fig. S1; Log-likelihood -218588), which is based on the following substitution models (selected according to the Bayesian Information Criterion): 18S: TIM+I+G4; 16S, 28S, COI \& H3: GTR+I+G4.

Topology-tests were run constraining the monophyly of Bivalvia and of Protobranchia to assess the strength of evidence for these previously well-resolved nodes (e.g., Sharma et al., 2012; Bieler et al., 2014; González et al., 2015). Log likelihoods of site patterns were generated in RAxML 8.2.8 on XSEDE (Stamatakis, 2014). Resulting suboptimal likelihood trees were then compared to the unconstrained tree ML topology, based on the same dataset, using CONSEL (Shimodaira and Hasegawa, 2001) to conduct the approximately unbiased (au; Shimodaira, 2002), Kishino-Hasegawa (kh), Shimodaira- 
Hasegawa (sh), weighted Kishino-Hasegawa (wkh) and weighted Shimodaira-Hasegawa (wsh) tests.

\section{Results and discussion}

This is the first phylogenetic study of a large molluscan clade (i.e., a class) including comparable dense sampling (i.e., 90 of the 108 families recognized by Bieler et al., 2010), using Sanger sequencing of traditional markers commonly used in bivalve systematicsthese same five markers are often referred to as the "work-horses" in previous molluscan literature (Sharma et al., 2012) or as the "usual suspects" in the arachnid literature (Dimitrov et al., 2016). As in virtually all previous phylogenetic analyses of bivalves using standard markers, the monophyly of Bivalvia and of Protobranchia are not supported (Figs. 1-2). We however tested these two specific hypotheses and our analyses are non-significant for rejection of the monophyly of Bivalvia for all five tests that we conducted (Table 3). In contrast, tree topologies that enforce the monophyly of Protobranchia are significantly worse than the unconstrained tree topology in four out of five likelihood-based topology tests (Table 3).

Irrespective of the lack of monophyly, our results (Figs. 1a, 2a) and all densely sampled previous analyses show protobranchs divided into four deep, well-supported clades, Solemyidae, Nucinellidae, Nuculidae, and Nuculanoidea; while Nuculidae and Nuculanoidea are sister groups, Solemyidae often clusters with the outgroups and Nucinellidae appears in different unsupported positions. No analysis finds monophyly of Solemyida (Solemyoidea + Nucinellidae ${ }^{2}$ ) (Oliver and Taylor, 2012), as already discussed by Sharma et al. (2013). Taxon sampling, however, allows us to discuss in more detail relationships within each of the four protobranch clades. In Solemyidae, Acharax is sister to a monophyletic Solemya; in Nuculidae, Nucula is paraphyletic with respect to Acila and Ennucula. Within Nuculanoidea most families represented by more than one specimen, with the exception of Neilonellidae, appear non-monophyletic; however, only Malletiidae appears in the two main nuculanoidean clades, one of which groups the malletiids Katadesmia and Clencharia with Tindariidae, Sareptidae, and Neilonellidae, while the other

\footnotetext{
${ }^{2}$ We follow other authors, e.g., Oliver and Taylor (2012) in separating Nucinellidae and Manzanellidae, and since their sister group relationship (in what would constitute the clade Manzanelloidea [see Bieler et al. 2010]) remains untested, we here refer only to Nucinellidae, the taxon represented molecularly.
} 
malletiid, Malletia, clusters with Bathyspinulidae, Nuculanidae, Phaseolidae, Siliculidae, and Yoldiidae (Figs. 1a, 2a).

The unstable position of Nucinellidae as sister group of Pteriomorphia in the Bayesian tree and as sister group of Autobranchia in the ML tree is an unexpected result with the increased taxon sampling of this analysis, as the monophyly of Autobranchia is otherwise uncontroversial (e.g., Waller, 1998; Giribet and Wheeler, 2002; Sharma et al., 2012; Bieler et al., 2014; González et al., 2015). Monophyly of Protobranchia, and more specifically the position of Nucinellidae, should be a focus of future studies using larger data sets, especially since the problematic clade Nucinellidae was not part of prior transcriptome-based phylogenomic analysis able to test Protobranchia monophyly (Smith et al., 2011; González et al., 2015; Kocot et al., 2016; Lemer et al., 2016).

Pteriomorphian monophyly is robustly supported, and, as in most previous analyses, its major clades are well resolved: Mytilidae, Ostreida (as well as its subclades Pinnidae, Ostreoidea, Pterioidea), Arcida, Anomioidea, Limidae, and Pectinoidea. All the analyses find maximum support for a clade composed of Arcida, Limida, and Pectinida, as found in recent densely-sampled phylogenomic analyses (Lemer et al., 2016), but Limidae nests within Pectinida, a result not supported in the same phylogenomic analyses. None of the analyses resolve the position of Mytilidae with high support. The phylogenomic analysis of Pteriomorphia has evaluated these hypotheses and their possible conflict, concluding that Arcida is the most likely sister group of the other Pteriomorphia, while Mytilidae forms the sister group of Ostreida (Lemer et al., 2016). That analysis also shows monophyly of Pectinida (= Anomioidea + Pectinoidea) to the exclusion of Limidae, a result supported by our ML analysis (Figs. 1-3).

Within Ostreida, Pterioidea is well resolved as a clade, but two families, Malleidae and Pteriidae, are not monophyletic: Malleus and Vulsella do not form a clade, and neither do Pteria and Pinctada. This is, however, consistent with prior findings about the relationships of Pterioidea (Steiner and Hammer, 2000; Giribet and Distel, 2003; Tëmkin, 2006; 2010; Xue et al., 2012). A phylogenetically sound system for Pterioidea, as in the cases of Nuculanoidea and Arcoida, remains elusive.

Internal relationships of the main pteriomorphian clades resolve between Mytilida + Ostreida and Arcida + Pectinida + Limida, with the limids being nested within Pectinida, as sister group to Pectinoidea. However neither the clade uniting Mytilida + Ostreida or Arcida 
with Pectinida-Limida receive sufficient support, again suggesting that these relationships require additional data to be resolved with confidence (Lemer et al., 2016).

With respect to the internal resolution of other pteriomorphian families, Arcidae is not supported as monophyletic, as is often found in other more focused analyses (see Combosch and Giribet, 2016), and neither is Propeamussiidae, as Cyclopecten is closer to Pectinidae than to Propeamussium, but support for the relationships within Pectinoidea is low (Fig. 1a, 3) and any family-level rearrangements awaits denser taxonomic sampling.

Our analyses provide robust support for the monophyly of Heteroconchia, Palaeoheterodonta, and support, although without significant posterior probability or bootstrap support, Heterodonta, Archiheterodonta, Euheterodonta, Anomalodesmata, and Imparidentia. All of these nodes also received robust support in the phylogenomic analysis of González et al. (2015), illustrating that the work-horse genes used here have signal when analyzed in combination, even though there may not be enough to provide consistently robust support at this level. This also stresses the fact that results based solely on mitochondrial genes are at odds with either the work-horses analyzed together or with the transcriptomic analyses, once more suggesting that mitochondrial genomes may not be sufficient for answering deep evolutionary questions within molluscs or for their relationships with other metazoan clades (Bernt et al., 2013; Stöger and Schrödl, 2013). This is why we do not feel compelled to discuss in any detail results based solely on COI and 16S rRNA in the context of the work conducted here.

Palaeoheterodonts divide into the marine Trigoniida and the freshwater clade Unionida, as in virtually every published bivalve phylogeny. Resolution within Unionida is, however, not well supported, and recent analyses have found alternative resolutions (e.g., Graf and Cummings, 2007; Whelan et al., 2011). For example, our ML tree supports Hyriidae as the sister group to the remaining families, followed by Unionidae and then by Margaritiferidae, which is sister group to a well-supported clade of Iridinidae, Etheriidae, and Mycetopodidae (Figs. 1a, 3), but our Bayesian analysis supports the latter clade as sister group to a monophyletic Hyriidae + Unionidae + Margaritiferidae (Fig. 2a). Resolution within Unionida seems to be highly sensitive to analytical parameters and methodologies (Whelan et al., 2011) as well as taxon sampling (Graf et al., 2015), and again it appears that additional data will be necessary to resolve this enigmatic Triassic radiation of freshwater bivalves (Bieler et al., 2014). 
Archiheterodont relationships are well resolved, with two clades, Carditoidea and Crassatelloidea, as shown in an earlier and more densely sampled study (González and Giribet, 2014), and corroborated phylogenomically (González et al., 2015). As in the former study, we find Condylocardiidae nested within Carditidae, and thus not representing a valid bivalve family. The division of Crassatelloidea in the two families Crassatellidae and Astartidae is well supported. Our results thus corroborate recent findings on the relationships of this clade of primitive heterodonts (González and Giribet, 2014).

Anomalodesmata is well supported as the sister clade to Imparidentia. Anomalodesmatan relationships have received attention both based on molecules and morphology (Harper et al., 2000; Harper et al., 2006; Healy et al., 2008), but little consensus has emerged (Bieler et al., 2014). Here we find good support for a clade including the members of the families Laternulidae, Clavagellidae, Lyonsiidae, and Pandoridae, but the latter two are not monophyletic; this clade corresponds to the 'lyonsiid' lineage of Harper et al. (2006). Clavagellidae is well supported as nested in the Lyonsiidae-Pandoridae clade. Verticordiidae, and Cuspidariidae form a clade of carnivorous bivalves, but it is not well supported, and the other carnivorous family, Poromyidae, does not group with them, and instead appears as the sister group of another well supported clade, composed of the members of the families Periplomatidae, Thraciidae, Cleidothaeridae, and Myochamidae, with Cleidothaerus nesting within Myochamidae. While Cleidothaeridae and Myochamidae have been considered separate families, the former consists of two currently recognized extant species (Morton and Harper, 2001), and is highly apomorphic due to the coiling of the shell, as Cleidothaerus cements by its robust, coiled, right valve to hard substrata. It is interesting that, although without significant support, Cleidothaerus is sister group to the other cementing Myochamidae, Myochama (see Harper and Morton, 2000), while the noncementing Myadora constitutes their sister group, indicating that cementation may have originated twice within Anomalodesmata and not three times as previously thought. In addition, Cleidothaerus and Myochamidae (i.e., Myadora and Myochama) are strictly Australasian taxa and both have first appearance data in the Oligocene (Beu and Maxwell, 1990; Beu and Raine, 2009).

The lack of support for the monophyly of the three septibranch families is probably due to the long branches of some of its members, especially Poromya illevis, and the clade has been difficult to recover in other Sanger-based analyses (Harper et al., 2006; Bieler et al., 2014). The accelerated evolutionary rates of some anomalodesmatan lineages are 
probably responsible for some of the lack of resolution among the deepest nodes, and a major effort should be directed toward generating transcriptomes for this group with many species adapted to highly specialized habitats, including the deep sea.

Relationships within Imparidentia have been difficult to resolve using standard Sanger-based approaches (e.g., Campbell, 2000; Steiner and Hammer, 2000; Giribet and Wheeler, 2002; Giribet and Distel, 2003; Williams et al., 2004; Taylor et al., 2007; Taylor et al., 2009; Sharma et al., 2012; Bieler et al., 2014), and our study corroborates the results of some of these previous studies. Despite increasing the taxon sampling in some poorly represented clades, many deep nodes remain poorly resolved, and new approaches are required to resolve some of the most recalcitrant nodes, such as Gastrochaenidae (see González et al., 2015) and Chamidae.

Our analyses confirm prior hypotheses of a basal position of Thyasiridae, Gastrochaenidae, and Lucinidae within Imparidentia, but relationships between these three families remain poorly supported, limiting the conclusions that may be drawn at present. The Bayesian analysis does add some support to the placement of Thyasiridae as sister group to all other imparidentians and to a clade of Gastrochaenidae + Lucinidae, but this result is contradicted by the phylogenomic analyses of González et al. (2015) which placed Gastrochaenidae as sister group to the non-lucinid imparidentians (that study did not sample Thyasiridae).

Our analyses also recover the clade Adapedonta, consisting of Hiatellidae + Solenoidea (the latter = Solenidae + Pharidae) (e.g., Taylor et al., 2007; Taylor et al., 2009; Bieler et al., 2014), although with low support. Adapedonta appears as the sister group of Galeommatoidea, although again, this relationship is not robustly supported, and while morphological evidence for Adapedonta may exist, no character has been proposed to group Galeommatoidea with Adapedonta, and this clade requires further testing.

Galeommatoidean relationships have received recent phylogenetic attention due to the interesting life habit adaptations of this diverse clade of bivalves (Goto et al., 2012; Li et al., 2016). Our taxon sampling does not overlap well with that of recent analyses, but we find major differences between our study and that of Goto et al. (2012), with Mysellidae being paraphyletic but basal to the other galeommatoids, followed by Lasaea (Lasaeidae) and then by a clade of Galeommatidae-Kelliidae. 
Cardiidae and Tellinoidea form a clade, as in previous phylogenetic analyses (e.g., Taylor et al., 2007; Taylor et al., 2009; Bieler et al., 2014), although again with marginal support and in clear need for additional evidence supporting this putative clade.

Internal relationships of Cardiidae are well supported, and once more show that Tridacna nests within the family, with Fragum as the most basal of the sampled species, i.e., the species is sister group to a clade including Tridacna and all the other species. However, sampling for Cardiidae is very limited in our study and lacks several basal lineages (see for example Herrera et al., 2015).

Tellinoidea is likewise monophyletic, but none of its families sampled by two or more species are resolved as monophyletic, indicating the need for thorough systematic reassessment of this commercially important clade. Of special interest is the Australian giant Plebidonax deltoides, which does not group with Donacidae, and instead nests within a paraphyletic Psammobiidae. The support for some nodes within this clade, and the current taxon sampling are not sufficient to propose taxonomic changes. Nevertheless, our study points to the urgency of work within this commercially important clade of bivalves.

Neoheterodontei is supported as monophyletic with the same composition as in Taylor et al. (2007); but the position of Chamidae inside or outside the Neoheterodontei requires further assessment (Bieler et al., 2014). Sphaeriidae appears as sister group to all other Neoheterodontei, a clade with few supported interfamilial relationships. One of the well-supported clades includes several members of the former Myoidea: Teredinidae + Pholadidae as sister group to Dreissenidae, Myidae, and Corbiculidae. Mactroidea (Mactridae + Mesodesmatidae) is also well supported, but Mesodesmatidae appears nested within a paraphyletic Mactridae. Ungulinidae + Cyamyioidea (Cyamiidae + Gaimardidae) also form a clade; in this case without significant support in the ML tree (Fig. 1b).

A clade uniting the Glossidae, Trapezidae, Hemidonacidae, Arctidae, Cyrenidae, Cyrenoididae, Glauconomidae, Vesicomyidae, Kelliellidae, Veneridae, and Chamidae is found consistently across analyses although it receives marginal support in the ML analysis (68\% bootstrap support; BS hereafter) and low posterior probability in the Bayesian analysis (pp $=0.83$ ). However, as a stable clade, it has been recovered by most analyses published to date (e.g., Taylor et al., 2007; Bieler et al., 2014) once more decoupling the notions of stability and support for certain clades (see Giribet, 2003). To evaluate the impact that the long-branched Chamidae may have in the resolution within the Imparidentia, we conducted an analysis with RAxML excluding all Chamidae (Fig. S2). The aforementioned clade was 
recovered with $96 \%$ BS, suggesting that the likely artefactual placement of Chamidae within Veneridae has widespread impact on the support of this clade and many of the subclades within it.

Glossidae, Trapezidae, Hemidonacidae, and Arctidae cluster together with the fresh/brackish-water clade of Cyrenidae, Cyrenoididae, and Glauconomidae, but the relationships between this latter clade and the other families is not well supported (Fig. 1b); indeed, in the Bayesian analysis, Glossidae + Trapezidae do not form a clade with Hemidonacidae, Arctidae, Cyrenidae, Cyrenoididae, and Glauconomidae (Fig. 2b). Additional sampling (taxa and genes) may be necessary to resolve this heterogeneous clade of Neoheterodontei.

Vesicomyidae and Kelliellidae form a well-supported clade, and appear as sister group to Veneridae, although without significant nodal support in the analyses including Chamidae; but this clade receives $84 \%$ BS when Chamidae is excluded. Veneridae appears paraphyletic with respect to the problematic and extremely long-branched Chamidae (see other sections of the discussion). Chama aside, the present results confirm the findings of Mikkelsen et al. (2006) who demonstrated that Veneridae divide into two clearly separated subgroups, with one clade including members of Tapetinae, Dosiniinae, Venerinae, and Chioninae, and a second clade spanning Petricolinae, Turtoniinae, and Gemminae (as well as other taxa not reinvestigated herein). The placement of Clementia/Clementiinae with the latter is a novel finding, as no representative was available for that earlier study.

The positions of two families, Gastrochaenidae and Chamidae, have been extremely difficult to resolve using Sanger-based approaches (e.g., Sharma et al., 2012; Bieler et al., 2014). Their placements find little support in our analyses and are probably responsible for the low support found in Imparidentia. The position of Gastrochaenidae was, however, well resolved in the phylogenomic analysis of González et al. (2015), appearing as sister group of the non-lucinid imparidentians, but that study did not include Thyasiridae-another key basal imparidentian—or Chamidae.

The phylogenetic position of Chamidae has long been disputed (e.g., Kennedy et al., 1970), among other things for being the only heterodont group in which a few species have distinct calcitic outer shell layers (Taylor and Kennedy, 1969; Harper, 1998), as found in hippuritids. The uncertain affinity of Chamidae based on shell microstructure or sperm ultrastructure has been discussed in detail by Taylor et al. (2007). Future transcriptomic analysis of additional imparidentian families is a promising avenue to resolve the position 
of a taxon once considered a surviving lineage of the extinct Mesozoic rudists (Newell, 1965; Yonge, 1967).

\section{Conclusions}

Through increased taxonomic sampling, we have been able to more densely populate the Bivalvia Tree of Life at the family level and place many species and genera in a broader phylogenetic context, as well as highlighting the need of denser taxon sampling in clades with poorly defined families, especially in Nuculanoidea, Arcoidea, and Tellinoidea. While it is now increasingly evident that Sanger sequencing of a small number of genes will not suffice to robustly resolve the deepest or most recalcitrant nodes, transcriptomic data is starting to be assembled toward this goal (González et al., 2015; Lemer et al., 2016). The application of transcriptomics to other molluscan clades has shown great promise in resolving the interrelationships of the molluscan classes (Kocot et al., 2011; Smith et al., 2011), and those of the megadiverse gastropods (Kocot et al., 2013; Zapata et al., 2014). Yet dense sampling at the species level may still rely on a Sanger approach or on the promising techniques for parallel massive amplicon sequencing (e.g., Faircloth et al., 2012; Lemmon and Lemmon, 2012). As for many other diverse and ancient clades, we thus see the future of bivalve systematics as a tiered approach, combining a well-resolved backbone based on genomic/transcriptomic data, with dense sampling of as many genera and species as possible using gene-target approaches. With this hybrid framework, we shall be positioned to tackle the most challenging evolutionary and ecological questions.

\section{Acknowledgements}

We are indebted to many colleagues who assisted with specimens and fieldwork throughout the overall project. Details, including collecting permit information, have been published earlier (Bieler et al. 2014: 105-106). Special thanks go to Philippe Bouchet, for several samples, Gustav Paulay for anomalodesmatan samples from Friday Harbor, Marina Cunha for Cadiz mus volcano samples. For laboratory work involving palaeoheterodont taxa we acknowledge John Pfeiffer and Nathan Whelan (University of Alabama). The Bivalve Assembling the Tree-of-Life project (http://www.bivatol.org) was supported by the US 
National Science Foundation (NSF) Assembling the Tree of Life (AToL) program (DEB0732854 / 0732903 / 0732860 ). 


\section{References}

Bernt, M., Bleidorn, C., Braband, A., Dambach, J., Donath, A., Fritzsch, G., Golombek, A., Hadrys, H., Jühling, F., Meusemann, K., Middendorf, M., Misof, B., Perseke, M., Podsiadlowski, L., von Reumont, B., Schierwater, B., Schlegel, M., Schrödl, M., Simon, S., Stadler, P.F., Stöger, I., Struck, T.H., 2013. A comprehensive analysis of bilaterian mitochondrial genomes and phylogeny. Mol. Phylogenet. Evol. 69, 352-364.

Beu, A.G., Maxwell, P.A., 1990. Cenozoic Mollusca of New Zealand. New Zealand Geological Survey Paleontological Bulletin 58, 1-518.

Beu, A.G., Raine, J.I., 2009. Revised descriptions of New Zealand Cenozoic Mollusca from Beu and Maxwell (1990). GNS Science Miscellaneous Series 27, http://www.gns.cri.nz/static/Mollusca/.

Bieler, R., Carter, J.G., Coan, E.V., 2010. Classification of bivalve families. Malacologia 52, 113133.

Bieler, R., Mikkelsen, P.M., Collins, T.M., Glover, E.A., González, V.L., Graf, D.L., Harper, E.M., Healy, J.M., Kawauchi, G.Y., Sharma, P.P., Staubach, S., Strong, E.E., Taylor, J.D., Tëmkin, I., Zardus, J.D., Clark, S., Guzmán, A., McIntyre, E., Sharp, P., Giribet, G., 2014. Investigating the Bivalve Tree of Life - an exemplar-based approach combining molecular and novel morphological characters. Invertebr. Syst. 28, 32-115.

Bieler, R., Mikkelsen, P.M., Giribet, G., 2013. Bivalvia - a discussion of known unknowns. Am. Malacol. Bull. 31, 123-133.

Campbell, D.C., 2000. Molecular evidence on the evolution of the Bivalvia. In: Harper, E.M., Taylor, J.D. Crame, J.A. (Eds.), The Evolutionary Biology of the Bivalvia. The Geological Society of London, London. pp. 31-46

Carter, J.G., Campbell, D.C., Campbell, M.R., 2000. Cladistic perspectives on early bivalve evolution. In: Harper, E.M., Taylor, J.D. Crame, J.A. (Eds.), The Evolutionary Biology of the Bivalvia. The Geological Society of London, London. pp. 47-79

Castresana, J., 2000. Selection of conserved blocks from multiple alignments for their use in phylogenetic analysis. Mol. Biol. Evol. 17, 540-552.

Combosch, D.J., Giribet, G., 2016. Clarifying phylogenetic relationships and the evolutionary history of the bivalve order Arcida (Mollusca: Bivalvia: Pteriomorphia). Mol.

Phylogenet. Evol. 94, 298-312. 
Cope, J.C.W., 2000. A new look at early bivalve phylogeny. In: Harper, E.M., Taylor, J.D. Crame, J.A. (Eds.), The Evolutionary Biology of the Bivalvia. The Geological Society of London, London. pp. 81-95

Darriba, D., Taboada, G.L., Doallo, R., Posada, D., 2012. jModelTest 2: more models, new heuristics and parallel computing. Nat. Methods 9, 772.

Dijkstra, H.H., Maestrati, P., 2012. Pectinoidea (Mollusca, Bivalvia, Propeamussiidae, Cyclochlamydidae n. fam., Entoliidae and Pectinidae) from the Vanuatu Archipelago. Zoosystema 34, 389-408.

Dimitrov, D., Benavides, L.R., Arnedo, M.A., Giribet, G., Griswold, C.E., Scharff, N., Hormiga, G., 2016. Rounding up the usual suspects: a standard target-gene approach for resolving the interfamilial phylogenetic relationships of ecribellate orb-weaving spiders with a new family-rank classification (Araneae, Araneoidea). Cladistics.

Doucet-Beaupré, H., Breton, S., Chapman, E.G., Blier, P.U., Bogan, A.E., Stewart, D.T., Hoeh, W.R., 2010. Mitochondrial phylogenomics of the Bivalvia (Mollusca): searching for the origin and mitogenomic correlates of doubly uniparental inheritance of mtDNA. BMC Evol. Biol. 10, 50.

Edgar, R.C., 2004. MUSCLE: multiple sequence alignment with high accuracy and high throughput. Nucleic Acids Res. 32, 1792-1797.

Faircloth, B.C., McCormack, J.E., Crawford, N.G., Harvey, M.G., Brumfield, R.T., Glenn, T.C., 2012. Ultraconserved elements anchor thousands of genetic markers spanning multiple evolutionary timescales. Syst. Biol. 61, 717-726.

Giribet, G., 2003. Stability in phylogenetic formulations and its relationship to nodal support. Syst. Biol. 52, 554-564.

Giribet, G., Distel, D.L., 2003. Bivalve phylogeny and molecular data. In: Lydeard, C. Lindberg, D.R. (Eds.), Molecular Systematics and Phylogeography of Mollusks. Smithsonian Books, Washington, D.C. pp. 45-90

Giribet, G., Wheeler, W.C., 2002. On bivalve phylogeny: a high-level analysis of the Bivalvia (Mollusca) based on combined morphology and DNA sequence data. Invertebr. Biol. 121, 271-324.

González, V.L., Andrade, S.C.S., Bieler, R., Collins, T.M., Dunn, C.W., Mikkelsen, P.M., Taylor, J.D., Giribet, G., 2015. A phylogenetic backbone for Bivalvia: an RNA-seq approach. Proc. R. Soc. B Biol. Sci. 282, 20142332. 
González, V.L., Giribet, G., 2014. A multilocus phylogeny of archiheterodont bivalves (Mollusca, Bivalvia, Archiheterodonta). Zool. Scr. 44, 41-58.

Goto, R., Kawakita, A., Ishikawa, H., Hamamura, Y., Kato, M., 2012. Molecular phylogeny of the bivalve superfamily Galeommatoidea (Heterodonta, Veneroida) reveals dynamic evolution of symbiotic lifestyle and interphylum host switching. BMC Evol. Biol. 12, 172.

Graf, D.L., Cummings, K.S., 2007. Review of the systematics and global diversity of freshwater mussel species (Bivalvia: Unionoida). J. Mollus. Stud. 73, 291-314.

Guindon, S., Dufayard, J.F., Lefort, V., Anisimova, M., Hordijk, W., Gascuel, O., 2010. New algorithms and methods to estimate maximum-likelihood phylogenies: Assessing the performance of PhyML 3.0. Syst. Biol. 59, 307-321.

Harper, E.M., 1998. Calcite in chamid bivalves. J. Mollus. Stud. 64, 391-399.

Harper, E.M., Dreyer, H., Steiner, G., 2006. Reconstructing the Anomalodesmata (Mollusca: Bivalvia): morphology and molecules. Zool. J. Linn. Soc. 148, 395-420.

Harper, E.M., Hide, E.A., Morton, B., 2000. Relationships between the extant Anomalodesmata: a cladistic test. In: Harper, E.M., Taylor, J.D. Crame, J.A. (Eds.), The Evolutionary Biology of the Bivalvia. The Geological Society of London, London. pp. 129-143

Harper, E.M., Morton, B., 2000. The biology and functional morphology of Myochama anomioides Stutchbury, 1830 (Bivalvia: Anomalodesmata: Pandoroidea), with reference to cementation. J. Mollus. Stud. 66, 403-416.

Healy, J.M., Bieler, R., Mikkelsen, P.M., 2008. Spermatozoa of the Anomalodesmata (Bivalvia, Mollusca) with special reference to relationships within the group. Acta Zool. 89, 339-350.

Herrera, N.D., ter Poorten, J.J., Bieler, R., Mikkelsen, P.M., Strong, E.E., Jablonski, D., Steppan, S.J., 2015. Molecular phylogenetics and historical biogeography amid shifting continents in the cockles and giant clams (Bivalvia: Cardiidae). Mol. Phylogenet. Evol. 93, 94-106.

Huber, M., 2015. Compendium of Bivalves 2. ConchBooks, Harxheim.

ICZN, 1999. International Code of Zoological Nomenclature. Fourth Edition. The International Trust for Zoological Nomenclature, London, UK.

Kennedy, W.J., Morris, N.J., Taylor, J.D., 1970. The shell structure, mineralogy and relationships of the Chamacea (Bivalvia). Palaeontology 13, 379-413. 
Kocot, K.M., Cannon, J.T., Todt, C., Citarella, M.R., Kohn, A.B., Meyer, A., Santos, S.R., Schander, C., Moroz, L.L., Lieb, B., Halanych, K.M., 2011. Phylogenomics reveals deep molluscan relationships. Nature 447, 452-456.

Kocot, K.M., Halanych, K.M., Krug, P.J., 2013. Phylogenomics supports Panpulmonata: Opisthobranch paraphyly and key evolutionary steps in a major radiation of gastropod molluscs. Mol. Phylogenet. Evol. 69, 764-771.

Kocot, K.M., Struck, T.H., Merkel, J., Waits, D.S., Todt, C., Brannock, P.M., Weese, D.A., Cannon, J.T., Moroz, L.L., Lieb, B., Halanych, K.M., 2016. Phylogenomics of Lophotrochozoa with consideration of systematic error. Syst. Biol.

Lemer, S., González, V.L., Bieler, R., Giribet, G., 2016. Cementing mussels to oysters in the pteriomorphian tree: A phylogenomic approach. Proc. R. Soc. B Biol. Sci. 283, 20160857.

Lemmon, A.R., Lemmon, E.M., 2012. High-throughput identification of informative nuclear loci for shallow-scale phylogenetics and phylogeography. Syst. Biol. 61, 745-761.

Li, J., Ó Foighil, D., Strong, E.E., 2016. Commensal associations and benthic habitats shape macroevolution of the bivalve clade Galeommatoidea. Proc. R. Soc. B Biol. Sci. 283, 20161006.

Mikkelsen, P.M., Bieler, R., Kappner, I., Rawlings, T.A., 2006. Phylogeny of Veneroidea (Mollusca: Bivalvia) based on morphology and molecules. Zool. J. Linn. Soc. 148, 439-521.

Miller, M.A., Pfeiffer, W., Schwartz, T. 2010. Creating the CIPRES science gateway for inference of large phylogenetic trees In Proceedings of the Gateway Computing Environments Workshop (GCE) New Orleans: 1-8.

Minh, B.Q., Nguyen, M.A.T., von Haeseler, A., 2013. Ultrafast approximation for phylogenetic bootstrap. Mol. Biol. Evol. 30, 1188-1195.

Morton, B., 2012. The functional morphology and inferred biology of the enigmatic South African 'quadrivalve' bivalve Clistoconcha insignis Smith, 1910 (Thracioidea: Clistoconchidae fam. nov.): another anomalodesmatan evolutionary eccentric. Trans. Roy. Soc. South Afr. 67, 59-89.

Morton, B., Harper, E.M., 2001. Cementation in Cleidothaerus albidus (Lamarck, 1819) (Bivalvia: Anomalodesmata: Pandoroidea). Moll. Res. 21, 1-15.

Newell, N.D., 1965. Classification of the Bivalvia. Am. Mus. Novit. 2206, 1-25. 
Newell, N.D., Boyd, D.W., 1978. A paleontologist's view of bivalve phylogeny. Philos. Trans. Roy. Soc. B Biol. Sci. 284, 203-214.

Nguyen, L.T., Schmidt, H.A., von Haeseler, A., Minh, B.Q., 2015. IQ-TREE: a fast and effective stochastic algorithm for estimating maximum-likelihood phylogenies. Mol. Biol. Evol. 32, 268-274.

Oliver, P.G., Taylor, J.D., 2012. Bacterial symbiosis in the Nucinellidae (Bivalvia: Solemyida) with descriptions of two new species. J. Mollus. Stud. 78, 81-91.

Plazzi, F., Ceregato, A., Taviani, M., Passamonti, M., 2011. A molecular phylogeny of bivalve mollusks: Ancient radiations and divergences as revealed by mitochondrial genes. PLoS One 6, e27147.

Plazzi, F., Ribani, A., Passamonti, M., 2013. The complete mitochondrial genome of Solemya velum (Mollusca: Bivalvia) and its relationships with Conchifera. BMC Genomics 14, 409.

Popham, J.D., 1979. Comparative spermatozoon morphology and bivalve phylogeny. Malacol. Rev. 12, 1-20.

Rambaut, A., Suchard, M.A., Xie, D., Drummond, A.J., 2014. Tracer v1.6, Available from http://beast.bio.ed.ac.uk/Tracer.

Ronquist, F., Teslenko, M., van der Mark, P., Ayres, D.L., Darling, A., Höhna, S., Larget, B., Liu, L., Suchard, M.A., Huelsenbeck, J.P., 2012. MrBayes 3.2: efficient Bayesian phylogenetic inference and model choice across a large model space. Syst. Biol. 61, 539-542.

Schrödl, M., Stöger, I., 2014. A review on deep molluscan phylogeny: old markers, integrative approaches, persistent problems. J. Nat. Hist. 48, 2773-2804.

Sharma, P.P., González, V.L., Kawauchi, G.Y., Andrade, S.C., Guzmán, A., Collins, T.M., Glover, E.A., Harper, E.M., Healy, J.M., Mikkelsen, P.M., Taylor, J.D., Bieler, R., Giribet, G., 2012. Phylogenetic analysis of four nuclear protein-encoding genes largely corroborates the traditional classification of Bivalvia (Mollusca). Mol. Phylogenet. Evol. 65, 64-74.

Sharma, P.P., Zardus, J.D., Boyle, E.E., González, V.L., Jennings, R.M., McIntyre, E., Wheeler, W.C., Etter, R.J., Giribet, G., 2013. Into the deep: A phylogenetic approach to the bivalve subclass Protobranchia. Mol. Phylogenet. Evol. 69, 188-204.

Shimodaira, H., 2002. An approximately unbiased test of phylogenetic tree selection. Syst. Biol. 51, 492-508. 
Shimodaira, H., Hasegawa, M., 2001. CONSEL: for assessing the confidence of phylogenetic tree selection. Bioinformatics 17, 1246-1247.

Smith, S.A., Wilson, N.G., Goetz, F.E., Feehery, C., Andrade, S.C.S., Rouse, G.W., Giribet, G., Dunn, C.W., 2011. Resolving the evolutionary relationships of molluscs with phylogenomic tools. Nature 480, 364-367.

Stamatakis, A., 2014. RAxML version 8: A tool for phylogenetic analysis and post-analysis of large phylogenies. Bioinformatics 30, 1312-1313.

Stamatakis, A., Hoover, P., Rougemont, J., 2008. A rapid bootstrap algorithm for the RAxML Web servers. Syst. Biol. 57, 758-771.

Steiner, G., Hammer, S., 2000. Molecular phylogeny of the Bivalvia inferred from 18S rDNA sequences with particular reference to the Pteriomorphia. In: Harper, E.M., Taylor, J.D. Crame, J.A. (Eds.), The Evolutionary Biology of the Bivalvia. The Geological Society of London, London. pp. 11-29

Steiner, G., Müller, M., 1996. What can 18S rDNA do for bivalve phylogeny? J. Mol. Evol. 43, 58-70.

Stöger, I., Schrödl, M., 2013. Mitogenomics does not resolve deep molluscan relationships (yet?). Mol. Phylogenet. Evol. 69, 376-392.

Taylor, J.D., Glover, E.A., Valentich-Scott, P., 2011. Not a "living fossil:" the eastern Pacific bivalve Tellidorella belongs with Lucinidae, not Cardiniidae. Nautilus 125, 75-78.

Taylor, J.D., Glover, E.A., Williams, S.T., 2009. Phylogenetic position of the bivalve family Cyrenoididae-removal from (and further dismantling of) the superfamily Lucinoidea. Nautilus 123, 9-13.

Taylor, J.D., Kennedy, W.J., 1969. The shell structure and mineralogy of Chama pellucida Broderip. Veliger 11, 391-398.

Taylor, J.D., Williams, S.T., Glover, E.A., Dyal, P., 2007. A molecular phylogeny of heterodont bivalves (Mollusca: Bivalvia: Heterodonta): new analyses of $18 \mathrm{~S}$ and $28 \mathrm{~S}$ rRNA genes. Zool. Scr. 36, 587-606.

Tëmkin, I., 2006. Morphological perspective on the classification and evolution of Recent Pterioidea (Mollusca: Bivalvia). Zool. J. Linn. Soc. 148, 253-312.

Tëmkin, I., 2010. Molecular phylogeny of pearl oysters and their relatives (Mollusca, Bivalvia, Pterioidea). BMC Evol. Biol. 10, 342. 
Vaidya, G., Lohman, D.J., Meier, R., 2011. SequenceMatrix: concatenation software for the fast assembly of multi-gene datasets with character set and codon information. Cladistics 27, 171-180.

Waller, T.R., 1998. Origin of the molluscan class Bivalvia and a phylogeny of major groups. In: Johnston, P.A. Haggart, J.W. (Eds.), Bivalves: An Eon of evolution -Palaeobiological studies honoring Norman D. Newell. University of Calgary Press, Calgary. pp. 1-45

Whelan, N.V., Geneva, A.J., Graf, D.L., 2011. Molecular phylogenetic analysis of tropical freshwater mussels (Mollusca: Bivalvia: Unionoida) resolves the position of Coelatura and supports a monophyletic Unionidae. Mol. Phylogenet. Evol. 61, 504514.

Williams, S.T., Taylor, J.D., Glover, E.A., 2004. Molecular phylogeny of the Lucinoidea (Bivalvia): non-monophyly and separate acquisition of bacterial chemosymbiosis. J. Mollus. Stud. 70, 187-202.

Xue, D.-X., Wang, H.-Y., Zhang, T., Zhang, S.-P., Xu, F.-S., 2012. 基于 28S rRNA 基因片段的翼 形亚纲(Bivalvia: Pteriomorphia)系统发育的初步研究 [Phylogenetic analysis of the subclass Pteriomorphia (Bivalvia) based on partial 28S rRNA sequence]. Oceanol. Limnol. Sin. 43, 348-356.

Yonge, C.M., 1967. Form, habit and evolution in the Chamidae (Bivalvia) with reference to the conditions in the rudists (Hippuritacea). Philos. Trans. Roy. Soc. B Biol. Sci. 252, 49-105.

Zapata, F., Wilson, N.G., Howison, M., Andrade, S.C.S., Jörger, K.M., Schrödl, M., Goetz, F.E., Giribet, G., Dunn, C.W., 2014. Phylogenomic analyses of deep gastropod relationships reject Orthogastropoda. Proc. R. Soc. B Biol. Sci. 281, 20141739. 


\section{Figure legends:}

Figure 1. Phylogenetic tree of bivalve relationships based on maximum likelihood analysis of five genes with RAxML $(\ln L=-228,263.429012)$. Numbers at the nodes indicate bootstrap resampling frequencies; only bootstrap values $>50 \%$ are reported; asterisks indicate a bootstrap support of $100 \%$. Colors identify higher clades.

Figure 2. Phylogenetic tree of bivalve relationships based on Bayesian inference of five genes. Numbers at the nodes indicate posterior probabilities $>0.90$; asterisks indicate a posterior probability of 1.0. Colors as in Figure 1.

Figure 3. Summary tree of phylogenetic relationships among bivalve families (based on Fig. 1). Family clades are collapsed (using FigTree v 1.3.1). Filled clades indicate monophyletic families, while unfilled clades indicate non-monophyletic family subclades. Numbers in parentheses indicate the number of species within collapsed clades. Bold numbers attached to family names indicate multiple occurrences of a family. Node support and colors are as in Fig. 1. 


\section{Tables:}

Table 1. List of samples including family, species identity, sampling locality, voucher accession and gene fragments (including NCBI accession numbers).

Table 2. Alignment data for the analyzed sequences and Modeltest results per partition. GB stands for GBlocks 0.91b (Castresana, 2000). H3 is histone H3; COI is cytochrome $c$ oxidase subunit I; $16 \mathrm{~S}$ is $16 \mathrm{~S}$ rRNA; $18 \mathrm{~S}$ is $18 \mathrm{~S}$ rRNA; and $28 \mathrm{~S}$ is $28 \mathrm{~S}$ rRNA.

\begin{tabular}{|c|c|c|c|c|c|c|}
\hline Locus & $\begin{array}{l}\text { Pre- } \\
\text { GB }\end{array}$ & Post-GB & $\begin{array}{l}\text { GB } \\
\text { removed }\end{array}$ & $\begin{array}{c}\text { Average } \\
\text { individual } \\
\text { sequence length }\end{array}$ & Range & $\begin{array}{l}\text { Modeltest } \\
\text { results }\end{array}$ \\
\hline H3 & 336 & 325 & $3 \%$ & 328 & $270-330$ & GTR+I+ \\
\hline $\mathrm{COI}$ & 709 & 631 & $11 \%$ & 660 & $535-710$ & GTR+I+ \\
\hline $16 \mathrm{~S}$ & 1430 & 382 & $73 \%$ & 480 & $380-840$ & GTR+I+ \\
\hline $18 \mathrm{~S}$ & 2722 & 1668 & $39 \%$ & 1780 & $1700-1990$ & TIM1+I+ \\
\hline $28 \mathrm{~S}$ & 2900 & 1894 & $35 \%$ & 2100 & $1830-2300$ & GTR+I+ $\Gamma$ \\
\hline Total & 8097 & 4900 & $39 \%$ & & & \\
\hline
\end{tabular}

Table 3. Results of the topology tests conducted with CONSEL.

\begin{tabular}{|c|c|c|c|c|c|c|c|c|c|c|}
\hline Ran & Constrain & obs & au & np & bp & pp & kh & sh & wkh & wsh \\
\hline \multirow{2}{*}{1} & \multirow{2}{*}{ Unconstrained } & & 0.89 & 0.87 & 0.86 & \multirow[b]{2}{*}{1} & 0.87 & 0.92 & 0.87 & 0.94 \\
\hline & & 20.9 & 6 & 0 & 3 & & 5 & 8 & 5 & 2 \\
\hline \multirow{2}{*}{2} & \multirow{2}{*}{ Monophyly Bivalvia } & \multirow{2}{*}{20.9} & 0.17 & 0.11 & 0.12 & 8.00E- & 0.12 & 0.22 & 0.12 & 0.28 \\
\hline & & & 4 & 4 & 2 & 10 & 5 & 0 & 5 & 0 \\
\hline \multirow{2}{*}{3} & Monophyly Bivalvia \& & \multirow{2}{*}{44.3} & 0.02 & 0.00 & 0.00 & $6.00 \mathrm{E}-$ & 0.03 & 0.03 & 0.03 & 0.07 \\
\hline & Protobranchia & & 6 & 9 & 9 & 20 & 1 & 1 & 1 & 5 \\
\hline \multirow{2}{*}{4} & Monophyly & \multirow{2}{*}{45.9} & 0.02 & 0.00 & 0.00 & $1.00 \mathrm{E}-$ & 0.02 & 0.02 & 0.02 & 0.05 \\
\hline & Protobranchia & & 5 & 5 & 6 & 20 & 1 & 2 & 1 & 4 \\
\hline
\end{tabular}

obs: observed log-likelihood difference. au: p-value of the approximately unbiased test calculated from the multiscale bootstrap (main result). np: bootstrap probability calculated from the multiscale bootstrap. bp: regular bootstrap 
probability. kh: Kishino-Hasegawa test. sh: Shimodaira-Hasegawa test. wkh: weighted Kishino-Hasegawa test. wsh: weighted Shimodaira-Hasegawa test. 


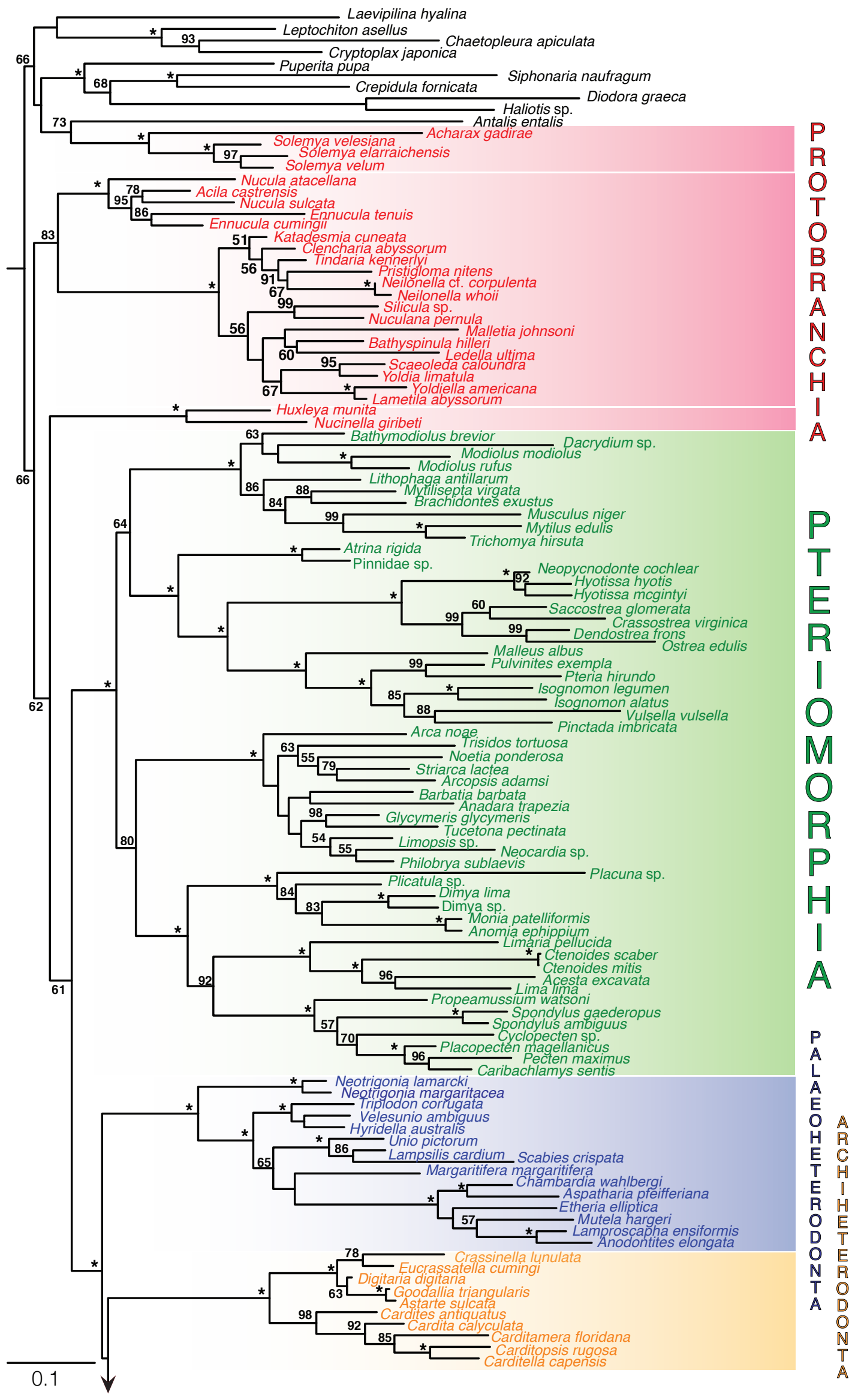




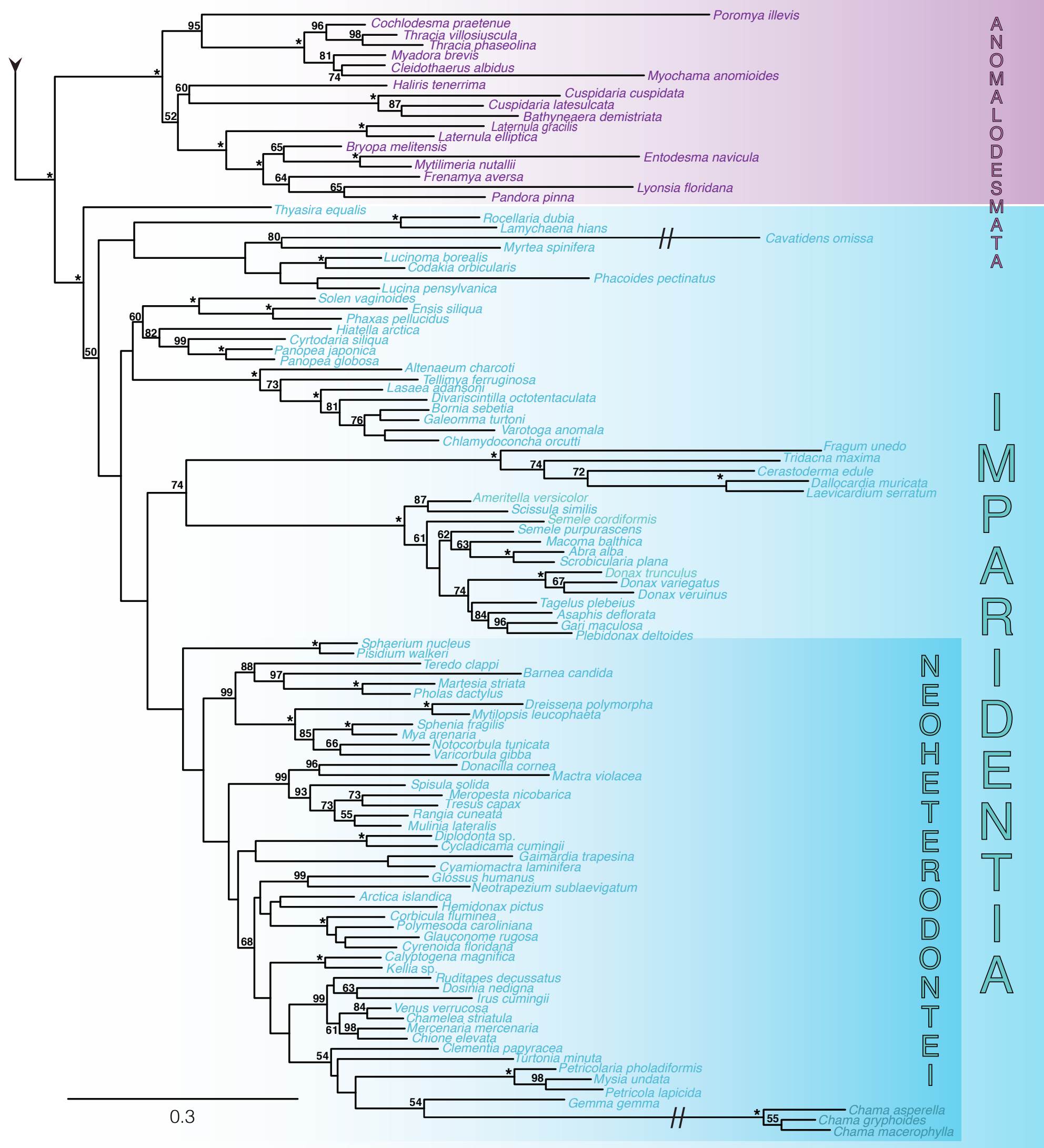




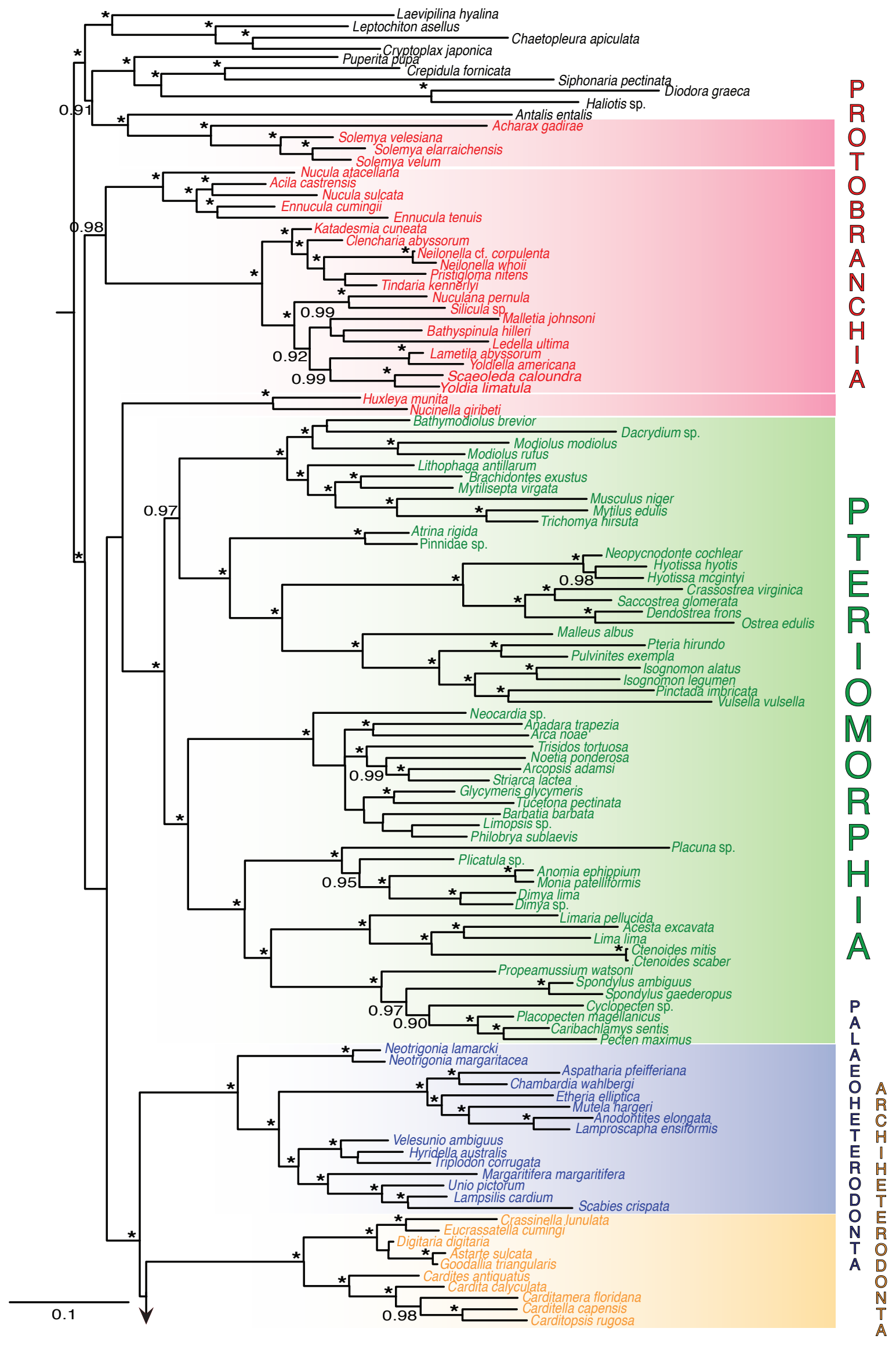




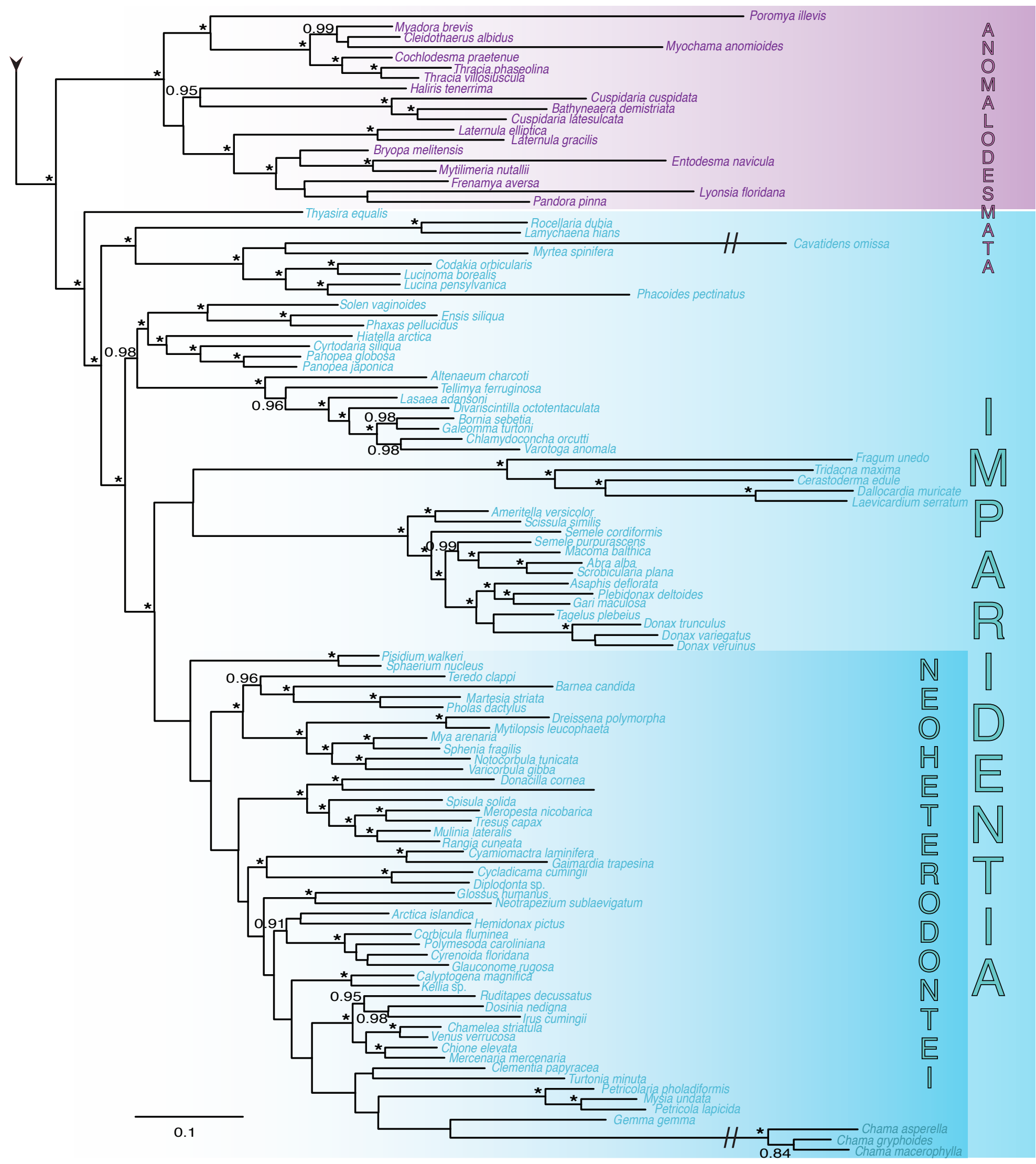


Figure 3

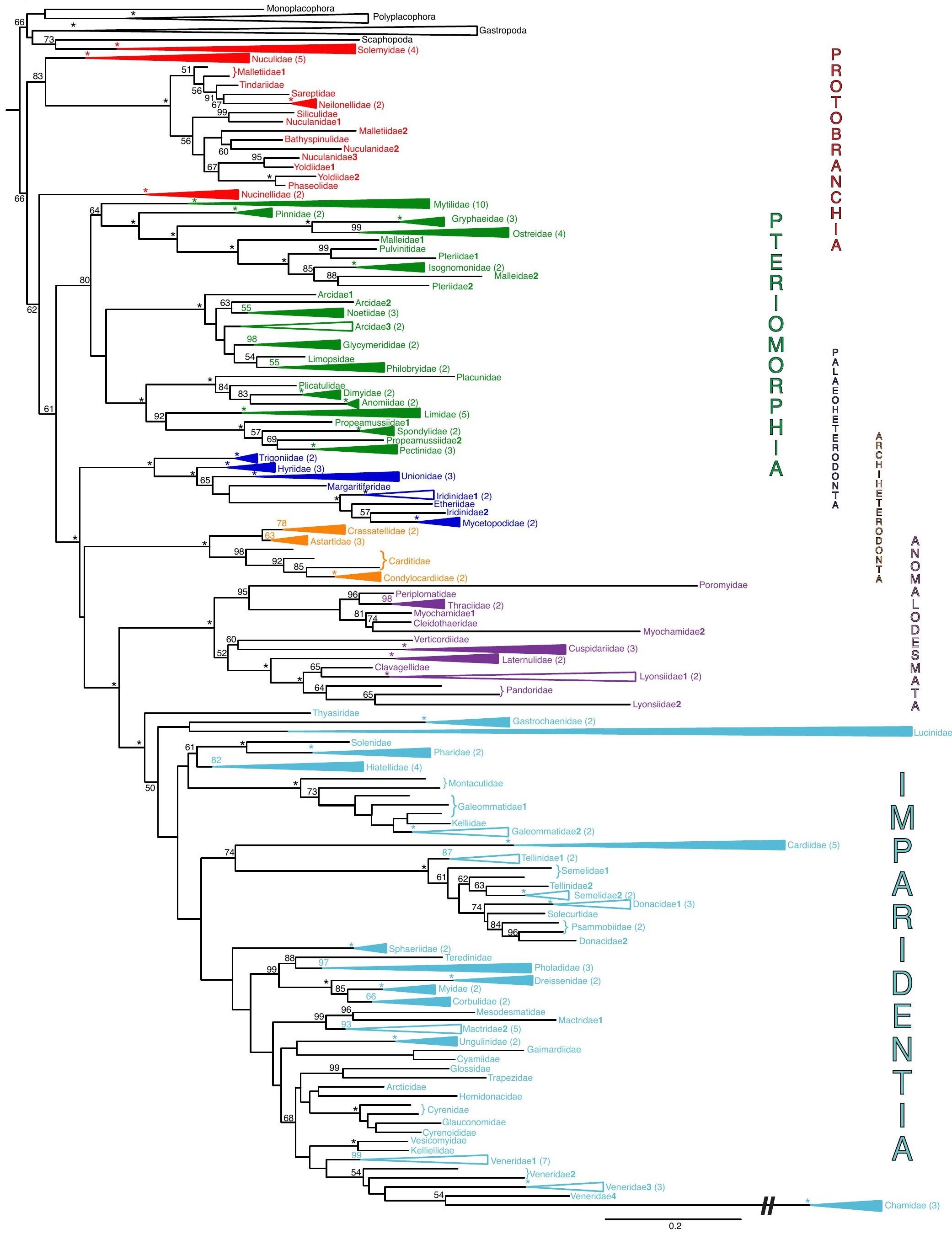

(2) 
Table1: List of samples including family, species identity, sampling locality, voucher accession and gene fragments (including NCBI accession numbers).

\begin{tabular}{|c|c|c|c|c|c|c|c|c|c|}
\hline Family & Species & & Locality & Accession & $18 S$ & $28 S$ & $16 S$ & H3 & $\mathrm{COI}$ \\
\hline \multicolumn{10}{|l|}{ PROTOBRANCHIA } \\
\hline Solemyidae & Solemya velesiana & Iredale, 1931 & $\begin{array}{l}\text { Australia, } \\
\text { Queensland }\end{array}$ & BivAToL-73 & KC984717 & KC984794 & KC984674 & KC984780 & KC984744 \\
\hline Solemyidae & Solemya velum & Say, 1822 & $\begin{array}{l}\text { USA, } \\
\text { Massachusetts }\end{array}$ & BivAToL-17 & AF120524 & KC429415 & JQ728447 & AY070146 & U56852 \\
\hline Solemyidae & Solemya elarraichensis & $\begin{array}{l}\text { Oliver, } \\
\text { Rodrigues \& } \\
\text { Cunha, } 2011\end{array}$ & $\begin{array}{l}\text { Spain, Gulf of } \\
\text { Cádiz }\end{array}$ & $\begin{array}{l}\text { MCZ } \\
379147\end{array}$ & KC984719 & KC984795 & KC984673 & KC984779 & KC984743 \\
\hline Solemyidae & Acharax gadirae & $\begin{array}{l}\text { Oliver, } \\
\text { Rodrigues \& } \\
\text { Cunha, } 2011\end{array}$ & $\begin{array}{l}\text { Spain, Gulf of } \\
\text { Cádiz }\end{array}$ & $\begin{array}{l}\text { MCZ } \\
378816\end{array}$ & KC984715 & KC984793 & KC984672 & KX713510 & - \\
\hline Nucinellidae & Huxleyia munita & (Dall, 1898) & USA, California & $\begin{array}{l}\text { BivAToL- } \\
137\end{array}$ & KC429323 & $\begin{array}{c}\text { KC429412- } \\
13\end{array}$ & - & KC429157 & - \\
\hline Nucinellidae & Nucinella giribeti & $\begin{array}{l}\text { Glover \& Taylor, } \\
2013\end{array}$ & $\begin{array}{l}\text { Philippines, } \\
\text { Panglao }\end{array}$ & $\begin{array}{l}\text { MCZ } \\
379095\end{array}$ & KC429324 & KC429414 & - & KC429158 & KC429089 \\
\hline Nuculidae & Acila castrensis & (Hinds, 1843) & USA, Washington & $\begin{array}{l}\text { BivAToL- } \\
205\end{array}$ & KC429319 & KC429408 & KC429241 & - & KC429087 \\
\hline Nuculidae & Nucula atacellana & Schenck, 1939 & $\begin{array}{l}\text { Gay Head- } \\
\text { Bermuda transect }\end{array}$ & $\begin{array}{l}\text { BivAToL- } \\
215\end{array}$ & KT757806 & KT757852 & KC984676 & KT757893 & KC984742 \\
\hline Nuculidae & Ennucula cumingii & (Hinds, 1843) & $\begin{array}{l}\text { Australia, } \\
\text { Queensland }\end{array}$ & BivATol-153 & KC984724 & KC984813 & KC984683 & KC984752 & KC984750 \\
\hline Nuculidae & Nucula sulcata & Bronn, 1831 & $\begin{array}{l}\text { Scotland/Sweden, } \\
\text { Tjärnö }\end{array}$ & $\begin{array}{l}\text { BivAToL- } \\
\text { 189/ AToL } \\
\text { T68 }\end{array}$ & AF207642 & DQ279960 & DQ280029 & DQ280001 & DQ280017 \\
\hline Nuculidae & Ennucula tenuis & (Montagu, 1808) & $\begin{array}{l}\text { Greenland, Disko } \\
\text { Island }\end{array}$ & $\begin{array}{l}\text { MCZ } \\
379107\end{array}$ & KC984684 & KC984826 & KC984682 & KC984775 & KC984747 \\
\hline Sareptidae & Pristigloma nitens & (Jeffreys, 1876) & & $\begin{array}{l}\text { UMASS } \\
\text { EN 10RCa }\end{array}$ & KC984708 & KC984833 & KC984670 & KC984786 & - \\
\hline Bathyspinulidae & Bathyspinula hilleri & $\begin{array}{l}\text { (Allen \& } \\
\text { Sanders, 1982) }\end{array}$ & & $\begin{array}{l}\text { UMASS } \\
\text { 3D534.2 }\end{array}$ & KC984712 & KC984806 & KC993874 & KC984773 & KC984733 \\
\hline Malletiidae & Clencharia abyssorum & $\begin{array}{l}\text { (Verrill \& Bush, } \\
\text { 1898) }\end{array}$ & $\begin{array}{l}\text { Gay Head- } \\
\text { Bermuda transect }\end{array}$ & $\begin{array}{l}\text { BivAToL- } \\
217\end{array}$ & KC429320 & KC429409 & - & KC429154 & - \\
\hline Malletiidae & Malletia johnsoni & Clarke, 1961 & $\begin{array}{l}\text { Gay Head- } \\
\text { Bermuda transect }\end{array}$ & $\begin{array}{l}\text { BivAToL- } \\
216\end{array}$ & KC993879 & KC984837 & KC993872 & KC993888 & - \\
\hline Malletiidae & Katadesmia cuneata & (Jeffreys, 1876) & & $\begin{array}{l}\text { UMASS } \\
\text { Ice142.5 }\end{array}$ & KC984697 & KX713391 & - & KC984759 & - \\
\hline Neilonellidae & Neilonella whoii & $\begin{array}{l}\text { Allen \& Sanders, } \\
1996\end{array}$ & $\begin{array}{l}\text { Gay Head- } \\
\text { Bermuda transect }\end{array}$ & $\begin{array}{l}\text { BivAToL- } \\
218\end{array}$ & KC984695 & KC984822 & KC984659 & KC984756 & KC984732 \\
\hline Neilonellidae & Neilonella cf. corpulenta & (Dall, 1881) & $\begin{array}{l}\text { Gay Head- } \\
\text { Bermuda transect }\end{array}$ & $\begin{array}{l}\text { BivAToL- } \\
218 X\end{array}$ & KX713324 & KX713412 & - & KX713564 & - \\
\hline Nuculanidae & Ledella ultima & $\begin{array}{l}\text { (E.A. Smith, } \\
\text { 1885) }\end{array}$ & $\begin{array}{l}\text { Gay Head- } \\
\text { Bermuda transect }\end{array}$ & $\begin{array}{l}\text { BivAToL- } \\
219\end{array}$ & KC984685 & KC984820 & KC984667 & KC984769 & KC984740 \\
\hline
\end{tabular}




\begin{tabular}{|c|c|c|c|c|c|c|c|c|c|}
\hline Nuculanidae & Nuculana pernula & $\begin{array}{l}\text { (O.F. Müller, } \\
\text { 1779) }\end{array}$ & Sweden, Tjärnö & $\begin{array}{l}\text { BivAToL- } \\
147\end{array}$ & KC984693 & KC984801 & - & KC984766 & KC984737 \\
\hline Nuculanidae & Scaeoleda caloundra & (Iredale, 1929) & $\begin{array}{l}\text { Australia, } \\
\text { Queensland }\end{array}$ & $\begin{array}{l}\text { BivAToL- } \\
100\end{array}$ & KC429321 & KC429410 & KC429242 & KC429155 & - \\
\hline Phaseolidae & Lametila abyssorum & $\begin{array}{l}\text { Allen \& Sanders, } \\
1973\end{array}$ & & $\begin{array}{l}\text { UMASS } \\
\text { EN_10UC1 }\end{array}$ & KC984705 & KC984798 & KC984661 & KC984783 & - \\
\hline Siliculidae & Silicula sp. & & Solomon Is. & $\begin{array}{l}\text { MCZ } \\
379143\end{array}$ & KC984703 & KC984840 & - & KC984762 & KC984734 \\
\hline Tindariidae & Tindaria kennerlyi & (Dall, 1897) & & $\begin{array}{l}\text { AMNH } \\
\text { PRTB011 }\end{array}$ & KC984702 & KC984812 & - & KC984755 & KC984731 \\
\hline Yoldiidae & Yoldia limatula & (Say, 1831) & $\begin{array}{l}\text { USA, } \\
\text { Massachusetts }\end{array}$ & BivAToL-19 & KC429322 & KC429411 & - & KC429156 & KC429088 \\
\hline Yoldiidae & Yoldiella americana & $\begin{array}{l}\text { Allen, Sanders \& } \\
\text { Hannah, } 1995\end{array}$ & & $\begin{array}{l}\text { UMASS } \\
\text { 3D8369.2 }\end{array}$ & KC984707 & KC984842 & KC984662 & KC984787 & KC984726 \\
\hline \multicolumn{10}{|l|}{ TERIOMORPHIA } \\
\hline Mytilidae & Bathymodiolus brevior & $\begin{array}{l}\text { Cosel, Métivier } \\
\text { \& Hashimoto, } \\
1994\end{array}$ & $\begin{array}{l}\text { Kilo Moana } \\
\text { hydrothermal vent, } \\
\text { Lau basin }\end{array}$ & $\begin{array}{l}\text { MCZ } \\
386945\end{array}$ & KX713272 & KX713360 & KX713195 & KX713515 & - \\
\hline Mytilidae & Brachidontes exustus & (Linnaeus, 1758) & USA, East Florida & $\begin{array}{l}\text { BivAToL- } \\
243\end{array}$ & KT757791 & KT757838 & KX713196 & - & KX713447 \\
\hline Mytilidae & Dacrydium sp. & & $\begin{array}{l}\text { Gay Head- } \\
\text { Bermuda transect }\end{array}$ & $\begin{array}{l}\text { BivAToL- } \\
212\end{array}$ & KX713285 & KX713372 & KX713210 & KX713529 & KX713456 \\
\hline Mytilidae & Lithophaga antillarum & $\begin{array}{l}\text { (d'Orbigny, } \\
1853 \text { ) }\end{array}$ & USA, Florida Keys & $\begin{array}{l}\text { BivAToL- } \\
292\end{array}$ & KX713308 & KX713397 & KX713229 & KX713550 & - \\
\hline Mytilidae & Modiolus modiolus & (Linnaeus, 1758) & UK, Wales & $\begin{array}{l}\text { BivAToL- } \\
197\end{array}$ & KX713314 & - & KX713235 & KX713557 & KX713479 \\
\hline Mytilidae & Modiolus rufus & $\begin{array}{l}\text { (Fischer von } \\
\text { Waldheim, } \\
\text { 1807) }\end{array}$ & $\begin{array}{l}\text { Australia, } \\
\text { Queensland }\end{array}$ & $\begin{array}{l}\text { BivAToL- } \\
154\end{array}$ & KC429330 & KC429423 & KC429248 & KC429165 & KC429094 \\
\hline Mytilidae & Musculus niger & $\begin{array}{l}\text { (J. E. Gray, } \\
1824)\end{array}$ & Norway & $\begin{array}{l}\text { MCZ } \\
379061\end{array}$ & KX713316 & KX713404 & - & - & KX713481 \\
\hline Mytilidae & Mytilus edulis & Linnaeus, 1758 & UK, England & $\begin{array}{l}\text { BivAToL- } \\
271\end{array}$ & KC429331 & KC429424 & KC429249 & KC429166 & KC429095 \\
\hline Mytilidae & Mytilisepta virgata & $\begin{array}{l}\text { (Wiegmann, } \\
\text { 1837) }\end{array}$ & China, Hong Kong & $\begin{array}{l}\text { BivAToL- } \\
426\end{array}$ & KX713322 & KX713410 & KX713241 & KX713562 & - \\
\hline Mytilidae & Trichomya hirsuta & (Lamarck, 1819) & $\begin{array}{l}\text { Australia, } \\
\text { Queensland }\end{array}$ & BivAToL-74 & KX713350 & KX713436 & KX713260 & KX713583 & KX713503 \\
\hline Arcidae & Anadara trapezia & $\begin{array}{l}\text { (Deshayes, } \\
\text { 1839) }\end{array}$ & $\begin{array}{l}\text { Australia, } \\
\text { Queensland }\end{array}$ & BivAToL-76 & KT757770 & KT757817 & KX713189 & KT757865 & KX713443 \\
\hline Arcidae & Arca noae & Linnaeus, 1758 & Spain, Catalonia & $\begin{array}{l}\text { BivAToL- } \\
116\end{array}$ & KC429325 & KC429416 & KX713192 & KC429160 & KC429090 \\
\hline Arcidae & Barbatia barbata & (Linnaeus, 1758) & Spain, Catalonia & $\begin{array}{l}\text { BivAToL- } \\
123\end{array}$ & KC429326 & $\begin{array}{c}\text { KC429417- } \\
18\end{array}$ & KC429244 & KC429161 & KC429091 \\
\hline Arcidae & Trisidos tortuosa & (Linnaeus, 1758) & $\begin{array}{l}\text { Australia, } \\
\text { Queensland }\end{array}$ & BivAToL-91 & KT757811 & KT757858 & KX713263 & KT757899 & KX713506 \\
\hline Glycymerididae & Glycymeris glycymeris & (Linnaeus, 1758) & $\begin{array}{l}\text { France, Atlantic } \\
\text { coast }\end{array}$ & $\begin{array}{l}\text { BivAToL- } \\
133\end{array}$ & KC429328 & KC429421 & KC429246 & KC429163 & KC429093 \\
\hline
\end{tabular}




\begin{tabular}{|c|c|c|c|c|c|c|c|c|c|}
\hline Glycymerididae & Tucetona pectinata & (Gmelin, 1791) & USA, Florida Keys & BivAToL-32 & KT757812 & KT757859 & KX713264 & KT757900 & KX713507 \\
\hline Noetiidae & Arcopsis adamsi & (Dall, 1886) & USA, Florida Keys & BivAToL-37 & KC429327 & $\begin{array}{c}\text { KC429419- } \\
20\end{array}$ & KC429245 & KC429162 & KC429092 \\
\hline Noetiidae & Noetia ponderosa & (Say, 1822) & $\begin{array}{l}\text { USA, South } \\
\text { Carolina }\end{array}$ & $\begin{array}{l}\text { BivAToL- } \\
210\end{array}$ & KT757793 & KT757840 & KX713244 & KT757882 & KX713487 \\
\hline Noetiidae & Striarca lactea & (Linnaeus, 1758) & Spain, Catalonia & $\begin{array}{l}\text { BivAToL- } \\
115\end{array}$ & AF120531 & KT757855 & KX713259 & KT757897 & KX713502 \\
\hline Limopsidae & Limopsis sp. B & & $\begin{array}{l}\text { Gay Head- } \\
\text { Bermuda transect }\end{array}$ & $\begin{array}{l}\text { BivAToL- } \\
213\end{array}$ & KC429329 & KC429422 & KC429247 & KC429164 & - \\
\hline Philobryidae & Neocardia sp. & & $\begin{array}{l}\text { South Africa, Port } \\
\text { Elizabeth }\end{array}$ & $\begin{array}{l}\text { MCZ } \\
378927\end{array}$ & KT757803 & KT757849 & - & KT757890 & KX713486 \\
\hline Philobryidae & Philobrya sublaevis & Pelseneer, 1903 & $\begin{array}{l}\text { Antartica, Adelaide } \\
\text { Island }\end{array}$ & $\begin{array}{l}\text { BivAToL- } \\
399\end{array}$ & KT757807 & KT757853 & - & KT757895 & - \\
\hline Pteriidae & Pinctada imbricata & Röding, 1798 & USA, Florida Keys & BivAToL-48 & KX713333 & KX713420 & - & KX713569 & KX713492 \\
\hline Pteriidae & Pteria hirundo & (Linnaeus, 1758) & Spain, Catalonia & $\begin{array}{l}\text { BivAToL- } \\
126\end{array}$ & KC429332 & KC429425 & KC429250 & KC429167 & AF120647 \\
\hline Isognomonidae & Isognomon alatus & (Gmelin, 1791) & USA, Florida Keys & BivAToL-30 & KC429333 & KC429426 & KC429251 & KC429168 & KC429096 \\
\hline Isognomonidae & Isognomon legumen & (Gmelin, 1791) & China, Hong Kong & $\begin{array}{l}\text { BivAToL- } \\
425\end{array}$ & KT757801 & KT757848 & - & KT757894 & KX713469 \\
\hline Malleidae & Malleus albus & Lamarck, 1819 & $\begin{array}{l}\text { Australia, } \\
\text { Queensland }\end{array}$ & BivAToL-79 & KC429334 & $\begin{array}{c}\text { KC429427- } \\
28\end{array}$ & KC429252 & KC429169 & KC429097 \\
\hline Malleidae & Vulsella vulsella & (Linnaeus, 1758) & $\begin{array}{l}\text { Australia, } \\
\text { Queensland }\end{array}$ & $\begin{array}{l}\text { BivAToL- } \\
102\end{array}$ & KX713354 & KX713440 & - & KX713587 & KX713508 \\
\hline Pulvinitidae & Pulvinites exempla & (Hedley, 1914) & $\begin{array}{l}\text { Australia, New } \\
\text { South Wales }\end{array}$ & $\begin{array}{l}\text { AMS } \\
\text { C.129659 }\end{array}$ & AJ414640 & AJ307540 & - & - & - \\
\hline Pinnidae & Atrina rigida & (Lightfoot, 1786) & USA, Florida Keys & BivAToL-14 & KX713270 & KX713359 & KX713194 & KX713514 & KX713446 \\
\hline Pinnidae* & Atrina rigida & Gmelin, 1791 & $\begin{array}{l}\text { USA, North } \\
\text { Carolina }\end{array}$ & $\begin{array}{l}\text { BivAToL- } \\
170\end{array}$ & KC429337 & $\begin{array}{c}\text { KC429431- } \\
32\end{array}$ & KC429255 & - & - \\
\hline Pinnidae* & Pinna carnea & Gmelin, 1791 & USA, Florida Keys & BivAToL-15 & - & - & - & KC429172 & KC429099 \\
\hline Ostreidae & Crassostrea virginica & (Gmelin, 1791) & USA, Florida & $\begin{array}{l}\text { BivAToL- } \\
276\end{array}$ & KC429335 & KC429429 & KC429253 & KC429170 & KC429098 \\
\hline Ostreidae & Dendostrea frons & (Linnaeus, 1758) & USA, Florida Keys & BivAToL-54 & KX713287 & KX713374 & KX713212 & KX713531 & - \\
\hline Ostreidae & Ostrea edulis & Linnaeus, 1758 & & $\begin{array}{l}\text { BivAToL- } \\
174\end{array}$ & KX713327 & KX713414 & KX713245 & KX713565 & KX713488 \\
\hline Ostreidae & Saccostrea glomerata & (Gould, 1850) & $\begin{array}{l}\text { Australia, } \\
\text { Queensland }\end{array}$ & BivAToL-77 & KX713341 & KX713428 & KX713252 & KX713576 & - \\
\hline Gryphaeidae & Hyotissa hyotis & (Linnaeus, 1758) & $\begin{array}{l}\text { Australia, } \\
\text { Queensland }\end{array}$ & $\begin{array}{l}\text { BivAToL- } \\
103\end{array}$ & KX713300 & KX713388 & KX713223 & KX713544 & - \\
\hline Gryphaeidae & Hyotissa mcgintyi & (Harry, 1985) & USA, Florida Keys & $\begin{array}{l}\text { BivAToL- } \\
275\end{array}$ & KC429336 & KC429430 & KC429254 & KC429171 & - \\
\hline Gryphaeidae & Neopycnodonte cochlear & (Poli, 1795) & Portugal, Açores & $\begin{array}{l}\text { MCZ } \\
379087\end{array}$ & KX713325 & KX713413 & - & - & - \\
\hline Anomiidae & Anomia ephippium & Linnaeus, 1758 & Spain, Catalonia & $\begin{array}{l}\text { BivAToL- } \\
124\end{array}$ & KX713269 & KX713358 & KX713191 & KX713513 & - \\
\hline Anomiidae & Monia patelliformis & (Linnaeus, 1767) & UK, Wales & $\begin{array}{l}\text { BivAToL- } \\
272\end{array}$ & KC429342 & KC429441 & KC429261 & KC429179 & - \\
\hline
\end{tabular}




\begin{tabular}{|c|c|c|c|c|c|c|c|c|c|}
\hline \\
\hline Placunidae & Placuna placenta & (Linnaeus, 1758) & $\begin{array}{l}\text { Singapore/Solomon } \\
\text { Is. }\end{array}$ & $\begin{array}{l}\text { MCZ } \\
379133\end{array}$ & KC429343 & KC429442 & - & KC429180 & KC429104 \\
\hline Dimyidae & Dimya lima & Bartsch, 1913 & Philippines & $\begin{array}{l}\text { BivAToL- } \\
177\end{array}$ & KC429344 & KX713375 & KX713213 & KC429181 & - \\
\hline Dimyidae & Dimya sp. & & Solomon Is. & $\begin{array}{l}\text { MCZ } \\
378956\end{array}$ & KX713288 & KX713376 & - & KX713532 & - \\
\hline Pectinidae & Caribachlamys sentis & (Reeve, 1853) & USA, Florida Keys & BivAToL-13 & KX713274 & KX713362 & KX713199 & KX713517 & - \\
\hline Pectinidae & Pecten maximus & (Linnaeus, 1758) & $\begin{array}{l}\text { France/UK, } \\
\text { England (fish } \\
\text { market) }\end{array}$ & $\begin{array}{l}\text { BivAToL- } \\
199\end{array}$ & AY070112 & $\begin{array}{l}\text { KC429435- } \\
\quad 36\end{array}$ & KC429258 & KC429175 & KC429102 \\
\hline Pectinidae & Placopecten magellanicus & (Gmelin, 1791) & $\begin{array}{l}\text { USA, } \\
\text { Massachusetts }\end{array}$ & $\begin{array}{l}\text { BivAToL- } \\
360\end{array}$ & KX713335 & KX713422 & KX713249 & KX713571 & - \\
\hline Propeamussiidae & Cyclopecten sp. & & $\begin{array}{l}\text { North Pacific, } \\
\text { Cortes Ridge }\end{array}$ & $\begin{array}{l}\text { BivAToL- } \\
138\end{array}$ & KX713283 & KX713371 & KX713208 & KX713527 & KX713454 \\
\hline Propeamussiidae & Propeamussium watsoni & $\begin{array}{l}\text { (E.A. Smith, } \\
\text { 1885) }\end{array}$ & Philippines & $\begin{array}{l}\text { BivAToL- } \\
179\end{array}$ & KC429340 & KC429437 & KC429259 & KC429176 & KC429103 \\
\hline Spondylidae & Spondylus ambiguus & Chenu, 1844 & USA, Florida Keys & $\begin{array}{l}\text { BivAToL- } \\
274\end{array}$ & KC429341 & $\begin{array}{l}\text { KC429438- } \\
40\end{array}$ & KC429260 & KC429177 & - \\
\hline Spondylidae & Spondylus gaederopus & Linnaeus, 1758 & $\begin{array}{l}\text { Spain, Balearic } \\
\text { Islands }\end{array}$ & MCZ & KT757808 & KT757854 & KX713258 & KT757896 & KX713501 \\
\hline Plicatulidae & Plicatula sp. & & China, Hong Kong & $\begin{array}{l}\text { BivA I OL- } \\
432\end{array}$ & KX713337 & KX713424 & - & KX713573 & - \\
\hline Limidae & Acesta excavata & (Fabricius, 1779) & Norway & $\begin{array}{l}\text { BivAToL- } \\
201\end{array}$ & KX713266 & KX713355 & KX713188 & KX713509 & KX713441 \\
\hline Limidae & Ctenoides scaber & (Born, 1778) & USA, Florida Keys & BivAToL-45 & KC429338 & KC429433 & KC429256 & KC429173 & KC429100 \\
\hline Limidae & Ctenoides mitis & (Lamarck, 1807) & USA, Florida Keys & BivAToL-28 & KT757792 & KT757839 & KX713206 & KT757881 & KX713451 \\
\hline Limidae & Lima lima & (Linnaeus, 1758) & Spain, Catalonia & $\begin{array}{l}\text { BivAToL- } \\
114\end{array}$ & KC429339 & KC429434 & KC429257 & KC429174 & KC429101 \\
\hline Limidae & Limaria pellucida & $\begin{array}{l}\text { (C.B. Adams, } \\
\text { 1846) }\end{array}$ & USA, Florida Keys & BivAToL-29 & KX713307 & KX713396 & KX713228 & KX713549 & KX713474 \\
\hline \multicolumn{10}{|c|}{ ALAEOHETERODONTA } \\
\hline Trigoniidae & Neotrigonia margaritacea & (Lamarck, 1804) & $\begin{array}{l}\text { Australia, } \\
\text { Tasmania }\end{array}$ & $\begin{array}{l}\text { MCZ } \\
379090\end{array}$ & KP068219 & KP068171 & KX713243 & KP068290 & KP068122 \\
\hline Trigoniidae & Neotrigonia lamarckii & (Gray, 1838) & $\begin{array}{l}\text { Australia, } \\
\text { Queensland }\end{array}$ & BivAToL-97 & KC429345 & KC429443 & KC429262 & KC429182 & KC429105 \\
\hline Etheriidae & Etheria elliptica & Lamarck, 1807 & Zambia & $\begin{array}{l}\text { BivAToL- } \\
404\end{array}$ & KX713296 & KX713384 & KX713219 & KX713540 & KX713462 \\
\hline Iridinidae & Aspatharia pfeifferiana & (Bernardi, 1860) & Zambia & $\begin{array}{l}\text { BivAToL- } \\
330\end{array}$ & KC429347 & KC429445 & KC429264 & KC429184 & KC429107 \\
\hline Iridinidae & Chambardia wahlbergi & (Krauss, 1848) & Zambia & $\begin{array}{l}\text { BivAToL- } \\
405\end{array}$ & KX713277 & KX713365 & KX713202 & KX713520 & KX713448 \\
\hline Iridinidae & Mutela hargeri & $\begin{array}{l}\text { (E. A. Smith, } \\
1908)\end{array}$ & Zambia & $\begin{array}{l}\text { BivAToL- } \\
401\end{array}$ & KX713317 & KX713405 & KX713237 & KX713559 & KX713482 \\
\hline Mycetopodidae & Anodontites elongata & $\begin{array}{l}\text { (Swainson, } \\
\text { 1823) }\end{array}$ & Peru & 323 & KX713268 & KX713357 & KX713190 & KX713512 & KX713444 \\
\hline
\end{tabular}




\begin{tabular}{|c|c|c|c|c|c|c|c|c|c|}
\hline & & & & BivAToL- & & & & & \\
\hline Mycetopodidae & Lamproscapha ensiformis & (Spix, 1827) & Peru & 382 & KX713304 & KX713393 & KX713225 & KX713546 & KX713471 \\
\hline Hyriidae & Hyridella australis & (Lamarck, 1819) & $\begin{array}{l}\text { Australia, New } \\
\text { South Wales }\end{array}$ & $\begin{array}{l}\text { BivAToL- } \\
378\end{array}$ & KX713301 & KX713389 & KX713224 & KX713545 & KX713467 \\
\hline Hyriidae & Triplodon corrugatus & (Lamarck, 1819) & Peru & $\begin{array}{l}\text { BivAToL- } \\
380\end{array}$ & KX713352 & KX713438 & KX713262 & KX713585 & KX713505 \\
\hline Hyriidae & Velesunio ambiguus & (Philippi, 1847) & $\begin{array}{l}\text { Australia, New } \\
\text { South Wales }\end{array}$ & $\begin{array}{l}\text { BivAToL- } \\
379\end{array}$ & KC429346 & KC429444 & KC429263 & KC429183 & KC429106 \\
\hline Unionidae & Lampsilis cardium & $\begin{array}{l}\text { Rafinesque, } \\
1820\end{array}$ & USA, Illinois & $\begin{array}{l}\text { BivAToL- } \\
421\end{array}$ & KX713305 & KX713394 & KX713226 & KX713547 & KX713472 \\
\hline Unionidae & Scabies crispata & (Gould, 1843) & $\begin{array}{l}\text { unknown [UK } \\
\text { aquarium trade] }\end{array}$ & $\begin{array}{l}\text { BivAToL- } \\
373\end{array}$ & KX713342 & KX713429 & KX713253 & KX713577 & - \\
\hline Unionidae & Unio pictorum & (Linnaeus, 1758) & UK, England & $\begin{array}{l}\text { BivA I OL- } \\
204\end{array}$ & KC429349 & KC429447 & KC429266 & KC429186 & KC429109 \\
\hline Margaritiferidae & Margaritifera margaritifera & (Linnaeus, 1758) & $\begin{array}{l}\text { U. K., Northern } \\
\text { Ireland (farmed) }\end{array}$ & $\begin{array}{l}\text { BivAToL- } \\
299\end{array}$ & KC429348 & KC429446 & KC429265 & KC429185 & KC429108 \\
\hline CHIHETERODON & & & & & & & & & \\
\hline Carditidae & Cardita calyculata & (Linnaeus, 1758) & Spain, Catalonia & $\begin{array}{l}\text { BivAToL- } \\
119\end{array}$ & KC429352 & KC429450 & - & KC429189 & KC429112 \\
\hline Carditidae & Carditamera floridana & Conrad, 1838 & USA, Florida Keys & BivAToL-31 & KP068196 & KР068148 & KX713198 & KР068269 & - \\
\hline Carditidae & Cardites antiquatus & (Linnaeus, 1758) & Spain, Catalonia & $\begin{array}{l}\text { MCZ } \\
379176\end{array}$ & KР068197 & KР068149 & - & KP068270 & КР068096 \\
\hline Crassatellidae & Crassinella lunulata & (Conrad, 1834) & $\begin{array}{l}\text { Panama, Bocas del } \\
\text { Toro }\end{array}$ & $\begin{array}{l}\text { MCZ } \\
379774\end{array}$ & KP068213 & KР068165 & - & KP068284 & KР068118 \\
\hline Crassatellidae & Eucrassatella cumingii & $\begin{array}{l}\text { (A. Adams, } \\
\text { 1854) }\end{array}$ & $\begin{array}{l}\text { Australla, } \\
\text { Queensland }\end{array}$ & BivAToL-83 & KC429350 & KC429448 & KC429267 & KC429187 & KC429110 \\
\hline Astartidae & Astarte sulcata & $\begin{array}{l}\text { (Da Costa, } \\
1778)\end{array}$ & Wales, UK & $\begin{array}{l}\text { BivAToL- } \\
192\end{array}$ & KC429351 & KC429449 & KX713193 & KC429188 & KC429111 \\
\hline Astartidae & Digitaria digitaria & (Linnaeus, 1758) & Spain, Andalusia & $\begin{array}{l}\text { BivAToL- } \\
120\end{array}$ & KP068174 & KP068124 & - & KP068247 & - \\
\hline Astartidae & Goodallia triangularis & (Montagu, 1803) & Spain, Andalusia & $\begin{array}{l}\text { MCZ } \\
378994\end{array}$ & KР068173 & KP068123 & - & KP068246 & - \\
\hline Condylocardiidae & Carditella capensis & E. A. Smith, & $\begin{array}{l}\text { South Africa, } \\
\text { Western Cape }\end{array}$ & $\begin{array}{l}\text { MCZ } \\
378903\end{array}$ & KP068206 & KP068157 & - & KP068278 & KP068112 \\
\hline Condylocardiidae & Carditopsis rugosa & $\begin{array}{l}\text { (Sowerby III, } \\
\text { 1892) }\end{array}$ & $\begin{array}{l}\text { South Africa, } \\
\text { Eastern Cape }\end{array}$ & $\begin{array}{l}\text { MCZ } \\
378909\end{array}$ & KP068209 & KP068160 & - & KP068281 & KP068115 \\
\hline ANOMALODESMAT/ & & & & & & & & & \\
\hline Clavagellidae & Bryopa melitensis & (Broderip, 1835) & Italy, Sorrento & $\begin{array}{l}\text { MCZ } \\
378923\end{array}$ & KX713273 & KX713361 & KX713197 & KX713516 & - \\
\hline Myochamidae & Myadora brevis & $\begin{array}{l}\text { (Sowerby I, } \\
1827)\end{array}$ & $\begin{array}{l}\text { Australia, } \\
\text { Queensland }\end{array}$ & $\begin{array}{l}\text { BivAToL- } \\
166\end{array}$ & KX713318 & KX713406 & KX713238 & KX713560 & KX713483 \\
\hline Myochamidae & Myochama anomioides & $\begin{array}{l}\text { Stutchbury, } \\
1830\end{array}$ & $\begin{array}{l}\text { Australia, } \\
\text { Queensland }\end{array}$ & BivAToL-84 & $\begin{array}{l}\text { KC429357/ } \\
\text { KC429358 }\end{array}$ & KC429457 & KC429272 & KC429195 & KC429116 \\
\hline
\end{tabular}




\begin{tabular}{|c|c|c|c|c|c|c|c|c|c|}
\hline Cleidothaeridae & Cleidothaerus albidus & (Lamarck, 1819) & $\begin{array}{l}\text { Australia, New } \\
\text { South Wales }\end{array}$ & $\begin{array}{l}\text { BivAToL- } \\
361\end{array}$ & KC429359 & KC429458 & KC429273 & - & KC429117 \\
\hline Pandoridae & Frenamya aversa & (Hedley, 1913) & $\begin{array}{l}\text { Australia, } \\
\text { Queensland }\end{array}$ & $\begin{array}{l}\text { BivAToL- } \\
162\end{array}$ & AM774486 & AM779660 & - & KC429190 & KX713463 \\
\hline Pandoridae & Pandora pinna & (Montagu, 1803) & $\begin{array}{l}\text { France, Banyuls } \\
\text { sur Mer }\end{array}$ & $\begin{array}{l}\text { MCZ } \\
379116\end{array}$ & KX713328 & KX713415 & GQ166569 & KX713566 & GQ166588 \\
\hline Thraciidae & Thracia phaseolina & (Lamarck, 1818) & UK, England & $\begin{array}{l}\text { BivAToL- } \\
266\end{array}$ & KC429356 & $\begin{array}{c}\text { KC429454- } \\
56\end{array}$ & KC429271 & KC429194 & KC429115 \\
\hline Thraciidae & Thracia villosiuscula & $\begin{array}{l}\text { (MacGillivray, } \\
1827 \text { ) }\end{array}$ & Sweden, Tjärno & $\begin{array}{l}\text { MCZ } \\
381367\end{array}$ & KX713349 & KX713435 & - & KX713582 & - \\
\hline Laternulidae & Laternula elliptica & (King, 1832) & $\begin{array}{l}\text { Antarctica, } \\
\text { Adelaide Island }\end{array}$ & $\begin{array}{l}\text { BivAToL- } \\
202\end{array}$ & KC429354 & KC429452 & KC429269 & KC429192 & - \\
\hline Laternulidae & Laternula gracilis & (Reeve, 1860) & $\begin{array}{l}\text { Australia, } \\
\text { Queensland }\end{array}$ & BivAToL-78 & KX713306 & KX713395 & KX713227 & KX713548 & - \\
\hline Periplomatidae & Cochlodesma praetenue & (Pulteney, 1799) & UK, England & $\begin{array}{l}\text { BivAToL- } \\
321\end{array}$ & KC429355 & KC429453 & KC429270 & KC429193 & KC429114 \\
\hline Cuspidariidae & Bathyneaera demistriata & $\begin{array}{l}\text { (Allen \& Morgan, } \\
\text { 1981) }\end{array}$ & $\begin{array}{l}\text { Gay Head- } \\
\text { Bermuda transect }\end{array}$ & $\begin{array}{l}\text { BivAToL- } \\
214\end{array}$ & KC429362 & $\begin{array}{c}\text { KC429463- } \\
64\end{array}$ & KC429276 & KC429198 & KC429118 \\
\hline Cuspidariidae & Cuspidaria latesulcata & $\begin{array}{l}\text { (Tennison } \\
\text { Woods, 1878) }\end{array}$ & $\begin{array}{l}\text { Australia, } \\
\text { Queensland }\end{array}$ & BivAToL-98 & KX713282 & KX713370 & KX713207 & KX713525 & - \\
\hline Cuspidariidae & Cuspidaria cuspidata & (Olivi, 1792) & Sweden & $\begin{array}{l}\text { BivAToL- } \\
110\end{array}$ & KX713281 & KX713369 & - & KX713524 & KX713452 \\
\hline Poromyidae & Poromya illevis & Hedley, 1913 & $\begin{array}{l}\text { Australia, } \\
\text { Queensland }\end{array}$ & $\begin{array}{l}\text { BivAToL- } \\
159\end{array}$ & KC429361 & $\begin{array}{c}\text { KC429461- } \\
62\end{array}$ & KC429275 & KC429197 & - \\
\hline Verticordiidae & Haliris tenerrima & $\begin{array}{l}\text { (Jaeckel \& } \\
\text { Thiele, 1931) }\end{array}$ & $\begin{array}{l}\text { Mozambique } \\
\text { channel }\end{array}$ & $\begin{array}{l}\text { BivAToL- } \\
305\end{array}$ & KC429360 & $\begin{array}{c}\text { KC429459- } \\
60\end{array}$ & KC429274 & KC429196 & - \\
\hline Lyonsiidae & Lyonsia floridana & Conrad, 1849 & USA, Florida & $\begin{array}{l}\text { BivAToL- } \\
248\end{array}$ & KC429353 & KC429451 & KC429268 & KC429191 & AF120654 \\
\hline Lyonsiidae & Mytilimeria nuttalli & Conrad, 1837 & USA, San Juan Is. & $\begin{array}{l}\text { MCZ } \\
377787\end{array}$ & KX713321 & KX713409 & KX713240 & - & - \\
\hline Lyonsiidae & Entodesma navicula & $\begin{array}{l}\text { (Adams \& } \\
\text { Reeve, 1850) }\end{array}$ & USA, San Juan Is. & UF & KX713295 & KX713383 & KX713218 & KX713539 & - \\
\hline \multicolumn{10}{|l|}{ PARIDENTIA } \\
\hline Lucinidae & Cavatidens omissa & Iredale, 1931 & $\begin{array}{l}\text { Australia, } \\
\text { Queensland }\end{array}$ & BivAToL-71 & KC429363 & KC429465 & KC429277 & KC429199 & KC429120 \\
\hline Lucinidae & Codakia orbicularis & (Linnaeus, 1758) & USA, Florida Keys & BivAToL-10 & KC429364 & KC429466 & - & - & $\begin{array}{l}\text { KC429121/ } \\
\text { AF12657 }\end{array}$ \\
\hline Lucinidae & Lucina pensylvanica & (Linnaeus, 1758) & USA, Florida Keys & BivAToL-50 & KC429365 & KC429467 & KC429278 & KX713551 & KC429119 \\
\hline Lucinidae & Lucinoma borealis & (Linnaeus, 1767) & UK, England & $\begin{array}{l}\text { BivAToL- } \\
265\end{array}$ & KX713309 & KX713398 & KX713230 & KX713552 & - \\
\hline Lucinidae & Phacoides pectinatus & (Gmelin, 1791) & USA, Florida & $\begin{array}{l}\text { BivAToL- } \\
278\end{array}$ & KX713331 & KX713418 & KX713247 & KX713568 & KX713490 \\
\hline Lucinidae & Myrtea spinifera & (Montagu, 1803) & $\begin{array}{l}\text { France, Banyuls } \\
\text { sur Mer }\end{array}$ & $\begin{array}{l}\text { MCZ } \\
379069\end{array}$ & KX713319 & KX713407 & KX713239 & AY070157 & AY070139 \\
\hline Thyasiridae & Thyasira equalis & $\begin{array}{l}\text { (Verrill \& Bush, } \\
\text { 1898) }\end{array}$ & Sweden & $\begin{array}{l}\text { BivAToL- } \\
374\end{array}$ & KC429367 & KC429469 & - & KC429200 & KC429122 \\
\hline
\end{tabular}




\begin{tabular}{|c|c|c|c|c|c|c|c|c|c|}
\hline Hemidonacidae & Hemidonax pictus & (Tryon, 1870) & $\begin{array}{l}\text { Australia, } \\
\text { Queensland }\end{array}$ & BivAToL-95 & KC429386 & KC429494 & KC429297 & KC429218 & - \\
\hline Arcticidae & Arctica islandica & (Linnaeus, 1767) & UK, Scotland & $\begin{array}{l}\text { BivAToL- } \\
191\end{array}$ & KC429377 & KC429482 & KC429288 & KC429210 & KX713445 \\
\hline Trapezidae & $\begin{array}{l}\text { Neotrapezium } \\
\text { sublaevigatum }\end{array}$ & (Lamarck, 1819) & $\begin{array}{l}\text { Thailand/China, } \\
\text { Hong Kong }\end{array}$ & $\begin{array}{l}\text { BivAToL- } \\
395\end{array}$ & KC429378 & KC429483 & KC429289 & KC429211 & KC429128 \\
\hline Cardiidae & Cerastoderma edule & (Linnaeus, 1758) & UK, England & BivAToL-21 & KC429384 & KC429492 & KC429296 & KC429217 & KC429134 \\
\hline Cardiidae & Dallocardia muricata & (Linnaeus, 1758) & $\begin{array}{l}\text { USA, South } \\
\text { Carolina }\end{array}$ & $\begin{array}{l}\text { BivAToL- } \\
207\end{array}$ & KX713286 & KX713373 & KX713211 & KX713530 & KX713457 \\
\hline Cardiidae & Fragum unedo & (Linnaeus, 1758) & $\begin{array}{l}\text { Australia, } \\
\text { Queensland }\end{array}$ & BivAToL-75 & KC429385 & KC429493 & KC429318 & KC429239 & KC429135 \\
\hline Cardiidae & Laevicardium serratum & (Linnaeus, 1758) & USA, Florida Keys & BivAToL-56 & KX713303 & KX713392 & - & - & KX713470 \\
\hline Cardiidae & Tridacna maxima & (Röding, 1798) & $\begin{array}{l}\text { Aquarium } \\
\text { specimen }\end{array}$ & $\begin{array}{l}\text { MCZ } \\
381362\end{array}$ & KX713351 & KX713437 & KX713261 & KX713584 & KX713504 \\
\hline Chamidae & Chama asperella & Lamarck, 1819 & China, Hong Kong & $\begin{array}{l}\text { BivAToL- } \\
434\end{array}$ & KX713275 & KX713363 & KX713200 & KX713518 & - \\
\hline Chamidae & Chama gryphoides & Linnaeus, 1758 & Spain, Catalonia & BivATol-117 & KX713276 & KX713364 & KX713201 & KX713519 & - \\
\hline Chamidae & Chama macerophylla & Gmelin, 1791 & USA, Florida Keys & BivAToL-36 & KC429369 & KC429471 & KC429281 & KC429202 & - \\
\hline Cyamiidae & Cyamiomactra laminifera & (Lamy, 1906) & Antarctic Peninsula & $\begin{array}{l}\text { BivAToL- } \\
398\end{array}$ & KC429382 & $\begin{array}{c}\text { KC429488- } \\
89\end{array}$ & KC429293 & - & KC429131 \\
\hline Cyrenidae & Corbicula fluminea & $\begin{array}{l}\text { (O.F. Müller, } \\
1774)\end{array}$ & USA, Florida & $\begin{array}{l}\text { BivAToL- } \\
242\end{array}$ & AF120557 & KC429490 & KC429294 & AY070161 & KC429132 \\
\hline Cyrenidae & Polymesoda caroliniana & (Bosc, 1801) & USA, Florida & $\begin{array}{l}\text { BivAToL- } \\
281\end{array}$ & KX713338 & KX713425 & KX713250 & - & - \\
\hline Glauconomidae & Glauconome rugosa & Reeve, 1844 & $\begin{array}{l}\text { Singapore (fish } \\
\text { market) }\end{array}$ & $\begin{array}{l}\text { BivAToL- } \\
198\end{array}$ & KC429392 & KC429500 & KC429302 & KC429223 & KC429140 \\
\hline Cyrenoididae & Cyrenoida floridana & Dall, 1896 & USA, Florida Keys & BivAToL-27 & KC429368 & KC429470 & KC429280 & KC429201 & KC429123 \\
\hline Dreissenidae & Dreissena polymorpha & (Pallas, 1771) & USA, Illinois & $\begin{array}{l}\text { BivAToL- } \\
300\end{array}$ & AF120552 & $\begin{array}{c}\text { KC429513- } \\
14\end{array}$ & DQ280038 & KC429234 & KC429149 \\
\hline Dreissenidae & Mytilopsis leucophaeata & (Conrad, 1831) & USA, Florida Keys & BivAToL-9 & KX713323 & KX713411 & KX713242 & KX713563 & KX713485 \\
\hline Gaimardiidae & Gaimardia trapesina & (Lamarck, 1819) & Tierra del Fuego & $\begin{array}{l}\text { BivAToL- } \\
397\end{array}$ & KX713297 & KX713385 & KX713220 & KX713541 & KX713464 \\
\hline Galeommatidae & Chlamydoconcha orcutti & Dall, 1884 & USA, California & BivATol-440 & KX713279 & KX713367 & KX713204 & KX713522 & KX713449 \\
\hline Galeommatidae & $\begin{array}{l}\text { Divariscintilla } \\
\text { octotentaculata }\end{array}$ & $\begin{array}{l}\text { (Mikkelsen \& } \\
\text { Bieler, 1992) }\end{array}$ & USA, Florida & $\begin{array}{l}\text { BivAToL- } \\
253\end{array}$ & KX713290 & KX713378 & KX713215 & KX713534 & KX713459 \\
\hline Galeommatidae & Galeomma turtoni & Turton, 1825 & Spain, Catalonia & $\begin{array}{l}\text { BivAToL- } \\
127\end{array}$ & KX713298 & KX713386 & KX713221 & KX713542 & - \\
\hline Galeommatidae & Varotoga anomala & $\begin{array}{l}\text { (Deshayes, } \\
1856)\end{array}$ & $\begin{array}{l}\text { Australia, } \\
\text { Queensland }\end{array}$ & BivAToL-80 & KC429371 & KC429473 & KC429283 & KC429204 & - \\
\hline Lasaeidae & Lasaea adansoni & (Gmelin, 1791) & UK, Wales/England & $\begin{array}{l}\text { BivAToL- } \\
268\end{array}$ & KC429370 & KC429472 & KC429282 & KC429203 & KC429124 \\
\hline Montacutidae & Altenaeum charcoti & (Lamy, 1906) & $\begin{array}{l}\text { Antarctica, } \\
\text { Adelaide Island }\end{array}$ & $\begin{array}{l}\text { BivAToL- } \\
203\end{array}$ & KC429372 & $\begin{array}{c}\text { KC429474- } \\
75\end{array}$ & - & KC429205 & - \\
\hline
\end{tabular}




\begin{tabular}{|c|c|c|c|c|c|c|c|c|c|}
\hline Montacutidae & Tellimya ferruginosa & (Montagu, 1803) & UK, England & $\begin{array}{l}\text { BivAToL- } \\
267\end{array}$ & $\begin{array}{l}\text { KC429476/ } \\
\text { KC429477 }\end{array}$ & KC429407 & KC429317 & KC429240 & KC429153 \\
\hline Kelliidae & Bornia sebetia & (Costa, 1829) & Spain, Catalonia & $\begin{array}{l}\text { BivAToL- } \\
122\end{array}$ & KC429373 & KC429478 & KC429284 & KC429206 & KC429125 \\
\hline Glossidae & Glossus humanus & (Linnaeus, 1758) & UK, Scotland & $\begin{array}{l}\text { BivAToL- } \\
200\end{array}$ & KC429379 & KC429484 & KC429290 & KC429212 & KX713466 \\
\hline Kelliellidae & Kellia sp. & & $\begin{array}{l}\text { Gay Head- } \\
\text { Bermuda transect }\end{array}$ & $\begin{array}{l}\text { BivAToL- } \\
211\end{array}$ & KC429380 & $\begin{array}{c}\text { KC429485- } \\
86\end{array}$ & KC429291 & KC429213 & KC429129 \\
\hline Vesicomyidae & Calyptogena magnifica & $\begin{array}{l}\text { Boss \& Turner, } \\
1980\end{array}$ & East Pacific Rise & $\begin{array}{l}\text { BivAToL- } \\
259\end{array}$ & KC429381 & KC429487 & KC429292 & KC429214 & KC429130 \\
\hline Mactridae & Mactra violacea & Gmelin, 1791 & China, Hong Kong & $\begin{array}{l}\text { BivAToL- } \\
430\end{array}$ & KX713310 & KX713399 & KX713231 & KX713553 & KX713475 \\
\hline Mactridae & Meropesta nicobarica & (Gmelin, 1791) & China, Hong Kong & $\begin{array}{l}\text { BivAToL- } \\
429\end{array}$ & KX713313 & KX713402 & KX713234 & KX713556 & KX713478 \\
\hline Mactridae & Mulinia lateralis & (Say, 1822) & USA, Florida & $\begin{array}{l}\text { BivAToL- } \\
246\end{array}$ & KX713315 & KX713403 & KX713236 & KX713558 & KX713480 \\
\hline Mactridae & Rangia cuneata & $\begin{array}{l}\text { (Sowerby I, } \\
\text { 1831) }\end{array}$ & USA, Florida & $\begin{array}{l}\text { BivAToL- } \\
280\end{array}$ & KC429401 & KC429509 & KC429310 & KC429232 & KC429146 \\
\hline Mactridae & Spisula solida & (Linnaeus, 1758) & $\begin{array}{l}\text { UK, England (fish } \\
\text { market) }\end{array}$ & $\begin{array}{l}\text { BivAToL- } \\
319\end{array}$ & KX713347 & KX713434 & KX713257 & KX713581 & 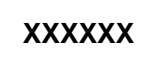 \\
\hline Mactridae & Tresus capax & (Gould, 1850) & $\begin{array}{l}\text { USA, Oregon } \\
\text { (fisheries) }\end{array}$ & $\begin{array}{l}\text { BivAToL- } \\
377\end{array}$ & KC429402 & KC429510 & KC429311 & - & KC429147 \\
\hline Mesodesmatidae & Donacilla cornea & (Poli, 1795) & Spain, Andalusia & $\begin{array}{l}\text { BivAToL- } \\
406\end{array}$ & KC429403 & $\begin{array}{l}\text { KC429511- } \\
12\end{array}$ & KC429312 & KC429233 & KC429148 \\
\hline Sphaeriidae & Pisidium walkeri & Sterki, 1895 & USA, Illinois & $\begin{array}{l}\text { BivAToL- } \\
303\end{array}$ & KX713334 & KX713421 & KX713248 & KX713570 & KX713493 \\
\hline Sphaeriidae & Sphaerium nucleus & (Studer, 1820) & UK, England & $\begin{array}{l}\text { BivAToL- } \\
194\end{array}$ & KC429383 & KC429491 & KC429295 & KC429216 & KC429133 \\
\hline Tellinidae & Ameritella versicolor & (DeKay, 1843) & USA, Florida & $\begin{array}{l}\text { BivAToL- } \\
256\end{array}$ & KX713267 & KX713356 & - & KX713511 & KX713442 \\
\hline Tellinidae & Macoma balthica & (Linnaeus, 1758) & UK, England & $\begin{array}{l}\text { BivAToL- } \\
186\end{array}$ & KC429393 & KC429501 & KC429303 & KC429224 & KC429141 \\
\hline Tellinidae & Scissula similis & $\begin{array}{l}\text { (Sowerby I, } \\
1806)\end{array}$ & USA, Florida Keys & BivAToL-7 & KC429394 & KC429502 & KC429304 & KC429225 & KC429142 \\
\hline Donacidae & Donax variegatus & (Gmelin, 1791) & Spain, Catalonia & $\begin{array}{l}\text { BivAToL- } \\
129\end{array}$ & KX713291 & KX713379 & - & KX713535 & KX713460 \\
\hline Donacidae & Plebidonax deltoides & (Lamarck, 1818) & $\begin{array}{l}\text { Australia, } \\
\text { Queensland }\end{array}$ & BivAToL-88 & KX713336 & KX713423 & - & KX713572 & KX713494 \\
\hline Donacidae & Donax trunculus & Linnaeus, 1758 & Spain, Catalonia & $\begin{array}{l}\text { BivAToL- } \\
132\end{array}$ & KC429395 & KC429503 & - & KC429226 & KC429143 \\
\hline Donacidae & Donax veruinus & Hedley, 1913 & $\begin{array}{l}\text { Australia, } \\
\text { Queensland }\end{array}$ & BivAToL-68 & KX713292 & KX713380 & - & KX713536 & - \\
\hline Psammobiidae & Asaphis deflorata & (Linnaeus, 1758) & USA, Florida Keys & BivAToL-33 & KC429396 & KC429504 & KC429305 & KC429227 & KC429144 \\
\hline Psammobiidae & Gari maculosa & (Lamarck, 1818) & China, Hong Kong & $\begin{array}{l}\text { BivAToL- } \\
423\end{array}$ & KX713299 & KX713387 & KX713222 & KX713543 & KX713465 \\
\hline Semelidae & Abra alba & (Wood, 1802) & UK, Scotland & $\begin{array}{l}\text { BivAToL- } \\
190\end{array}$ & KC429397 & KC429505 & KC429306 & KC429228 & - \\
\hline
\end{tabular}




\begin{tabular}{|c|c|c|c|c|c|c|c|c|c|}
\hline Semelidae & Scrobicularia plana & $\begin{array}{l}\text { (Da Costa, } \\
1778)\end{array}$ & UK, Wales & BivAToL-20 & KX713343 & KX713430 & KX713254 & KX713578 & KX713497 \\
\hline Semelidae & Semele cordiformis & (Holten, 1802) & China, Hong Kong & $\begin{array}{l}\text { BivAToL- } \\
424\end{array}$ & KX713344 & KX713431 & KX713255 & KX713579 & KX713498 \\
\hline Semelidae & Semele purpurascens & (Gmelin, 1791) & USA, Florida Keys & BivAToL-55 & KX713345 & KX713432 & - & - & KX713499 \\
\hline Solecurtidae & Tagelus plebeius & (Lightfoot, 1786) & USA, Florida & $\begin{array}{l}\text { BivAToL- } \\
245\end{array}$ & KC429398 & KC429506 & KC429307 & KC429229 & - \\
\hline Ungulinidae & Cycladicama cumingii & (Hanley, 1844) & Singapore & $\begin{array}{l}\text { BivAToL- } \\
371\end{array}$ & KC429366 & KC429468 & KC429279 & KX713526 & KX713453 \\
\hline Ungulinidae & Diplodonta sp. & & China, Hong Kong & $\begin{array}{l}\text { BivAToL- } \\
313\end{array}$ & KX713289 & KX713377 & KX713214 & KX713533 & KX713458 \\
\hline Veneridae & Chamelea striatula & $\begin{array}{l}\text { (Da Costa, } \\
1778)\end{array}$ & UK, England & $\begin{array}{l}\text { BivAToL- } \\
270\end{array}$ & KX713278 & KX713366 & KX713203 & KX713521 & - \\
\hline Veneridae & Chione elevata & (Say, 1822) & USA, Florida Keys & BivAToL-4 & KC429387 & KC429495 & KC429298 & KC429219 & KC429136 \\
\hline Veneridae & Clementia papyracea & (Gray, 1825) & $\begin{array}{l}\text { Australia, } \\
\text { Queensland }\end{array}$ & $\begin{array}{l}\text { BivAToL- } \\
228\end{array}$ & KX713280 & KX713368 & KX713205 & KX713523 & KX713450 \\
\hline Veneridae & Dosinia nedigna & (Iredale, 1930) & $\begin{array}{l}\text { Australia, } \\
\text { Queensland }\end{array}$ & $\begin{array}{l}\text { BivAToL- } \\
156\end{array}$ & KX713293 & KX713381 & KX713216 & KX713537 & KX713461 \\
\hline Veneridae & Gemma gemma & (Totten, 1834) & $\begin{array}{l}\text { USA, } \\
\text { Massachusetts }\end{array}$ & BivAToL-16 & KC429388 & KC429496 & KC429299 & KC429220 & KC429137 \\
\hline Veneridae & Mercenaria mercenaria & (Linnaeus, 1758) & $\begin{array}{l}\text { USA, South } \\
\text { Carolina }\end{array}$ & $\begin{array}{l}\text { BivAToL- } \\
208\end{array}$ & KX713312 & KX713401 & KX713233 & KX713555 & KX713477 \\
\hline Veneridae & Mysia undata & (Pennant, 1777) & Sweden & $\begin{array}{l}\text { BivAToL- } \\
111\end{array}$ & KX713320 & KX713408 & - & KX713561 & KX713484 \\
\hline Veneridae & Petricola lapicida & (Gmelin, 1791) & USA, Florida Keys & BivAToL-34 & KC429389 & KC429497 & KC429300 & KC429221 & KC429138 \\
\hline Veneridae & Irus cumingii & $\begin{array}{l}\text { (Deshayes, } \\
\text { 1854) }\end{array}$ & $\begin{array}{l}\text { Australia, } \\
\text { Queensland }\end{array}$ & BivAToL-72 & KX713302 & KX713390 & - & - & KX713468 \\
\hline Veneridae & Petricolaria pholadiformis & (Lamarck, 1818) & UK, England & BivAToL-22 & KX713330 & KX713417 & - & KX713567 & - \\
\hline Veneridae & Ruditapes decussatus & (Lamarck, 1818 & UK, England & $\begin{array}{l}\text { BivAToL- } \\
269\end{array}$ & KX713340 & KX713427 & KX713251 & KX713575 & KX713496 \\
\hline Veneridae & Turtonia minuta & (Fabricius, 1780) & Iceland & $\begin{array}{l}\text { FMNH } \\
302008\end{array}$ & KC429390 & KC429498 & - & DQ184898 & DQ184850 \\
\hline Veneridae & Venus verrucosa & Linnaeus, 1758 & $\begin{array}{l}\text { France, Atlantic } \\
\text { (fish market) }\end{array}$ & $\begin{array}{l}\text { BivAToL- } \\
176\end{array}$ & KC429391 & KC429499 & KC429301 & KC429222 & KC429139 \\
\hline Myidae & Mya arenaria & Linnaeus, 1758 & $\begin{array}{l}\text { USA, } \\
\text { Massachusetts }\end{array}$ & BivAToL-18 & AF120560 & KC429515 & KC429313 & AY070164 & KC429150 \\
\hline Myidae & Sphenia fragilis & $\begin{array}{l}\text { (A. Adams \& H. } \\
\text { Adams, 1854) }\end{array}$ & USA, Florida & $\begin{array}{l}\text { BivAToL- } \\
251\end{array}$ & KX713346 & KX713433 & KX713256 & KX713580 & - \\
\hline Corbulidae & Notocorbula tunicata & (Reeve, 1843) & $\begin{array}{l}\text { Australia, } \\
\text { Queensland }\end{array}$ & BivAToL-85 & KX713326 & KC429516 & KC429314 & KC429236 & KC429151 \\
\hline Corbulidae & Varicorbula gibba & (Olivi, 1792) & Sweden, Tjärnö & $\begin{array}{l}\text { BivAToL- } \\
118\end{array}$ & KX713353 & KX713439 & KX713265 & KX713586 & - \\
\hline Pholadidae & Barnea candida & (Linnaeus, 1758) & UK, England & BivAToL-25 & KX713271 & KC429517 & KC429315 & KC429237 & KC429152 \\
\hline Pholadidae & Martesia striata & (Linnaeus, 1758) & USA, Florida & $\begin{array}{l}\text { BivAToL- } \\
250\end{array}$ & KX713311 & KX713400 & KX713232 & KX713554 & KX713476 \\
\hline Pholadidae & Pholas dactylus & Linnaeus, 1758 & UK, England & BivAToL-24 & KX713332 & KX713419 & - & - & KX713491 \\
\hline
\end{tabular}




\begin{tabular}{|c|c|c|c|c|c|c|c|c|c|}
\hline Teredinidae & Teredo clappi & Bartsch, 1923 & USA, Florida Keys & BivAToL-59 & KX713348 & KC429518 & KC429316 & KC429238 & - \\
\hline Hiatellidae & Cyrtodaria siliqua & (Spengler, 1793) & $\begin{array}{l}\text { Canada, Nova } \\
\text { Scotia }\end{array}$ & $\begin{array}{l}\mathrm{MCZ} \\
384329\end{array}$ & KX713284 & - & KX713209 & KX713528 & KX713455 \\
\hline Hiatellidae & Hiatella arctica & (Linnaeus, 1767) & UK, England & $\begin{array}{l}\text { BivAToL- } \\
195\end{array}$ & KC429375 & KC429480 & KC429286 & KC429208 & KC429127 \\
\hline Hiatellidae & Panopea japonica & A. Adams, 1850 & $\begin{array}{l}\text { Japan, Fukuoka } \\
\text { (fish market) }\end{array}$ & $\begin{array}{l}\text { MCZ } \\
379117\end{array}$ & KC429374 & KC429479 & KC429285 & KC429207 & KC429126 \\
\hline Hiatellidae & Panopea globosa & Dall, 1898 & $\begin{array}{l}\text { China, Hong Kong } \\
\text { (fish market) }\end{array}$ & $\begin{array}{l}\text { BivAToL- } \\
431\end{array}$ & KX713329 & KX713416 & KX713246 & - & KX713489 \\
\hline Solenidae & Solen vaginoides & Lamarck, 1818 & $\begin{array}{l}\text { Australia, } \\
\text { Queensland }\end{array}$ & BivAToL-70 & KC429399 & KC429507 & KC429308 & KC429230 & - \\
\hline Pharidae & Ensis siliqua & (Linnaeus, 1758) & UK, England & BivAToL-26 & KX713294 & KX713382 & KX713217 & KX713538 & - \\
\hline Pharidae & Phaxas pellucidus & (Pennant, 1777) & Sweden, Tjärnö & $\begin{array}{l}\text { BivAToL- } \\
135\end{array}$ & KC429400 & KC429508 & KC429309 & KC429231 & KC429145 \\
\hline Gastrochaenidae & Rocellaria dubia & (Pennant, 1777) & Spain, Catalonia & MCZ & KX713339 & KX713426 & - & KX713574 & KX713495 \\
\hline Gastrochaenidae & Lamychaena hians & (Gmelin, 1791) & USA, Florida Keys & $\begin{array}{l}\text { BivAToL- } \\
289\end{array}$ & KC429376 & KC429481 & KC429287 & KC429209 & KX713473 \\
\hline
\end{tabular}

\section{OUTGROUPS}

Polyplacophora

Leptochitonidae

Cryptoplacidae

Chaetopleuridae

Leptochiton asellus

\section{(Gmelin, 1791)}

Sweden, Tjärnö

Pilsbry, 1901

Cryptoplax japonica

Chaetopleura apiculata

Say in Conrad,

1834)

GenBank

USA.

Massachussetts

Protostome

AToL T53

$\mathrm{n} / \mathrm{a}$

Protostome

AToL000234

AY145382

AY377656

AY145414

AY377586

AY377734

FJ461256

AY377636

AY145402

AY377611

AY377761 FJ445780

AY145398

AY377590

AY377741 AY377704

\section{Monoplacophora}

Neopilinidae

Laevipilina hyalina

(McLean, 1979)

USA, California

MCZ

378012

FJ445774

FJ449541

FJ449543

FJ445778

FJ445781

\section{Scaphopoda}

Dentaliidae

Antalis entalis

(Linnaeus, 1758) Sweden, Tjärnö

Protostome

AToL T7

DQ279936

AY145388

DQ280027

DQ280000

DQ280016

\section{Gastropoda}

Haliotidae

Haliotidae

Haliotis tuberculata

Linnaeus, 1758 Spain, Catalonia

MCZ

Reeve, 1846

GenBank

GQ160787

$-$
AY3777
AY377622 AY3777775 


\begin{tabular}{|c|c|c|c|c|c|c|c|c|c|}
\hline Fissurellidae & Diodora graeca & (Linnaeus, 1758) & Spain, Catalonia & $\begin{array}{l}\text { MCZ } \\
378383\end{array}$ & AF120513 & DQ279980 & DQ093476 & DQ093502 & AF120632 \\
\hline Neritidae & Puperita pupa & (Linnaeus, 1767) & Bahamas, Abaco & $\begin{array}{l}\text { MCZ } \\
378699\end{array}$ & FJ977656 & FJ977688 & FJ977719 & - & FJ977767 \\
\hline Calyptraeidae & Crepidula fornicata & (Linnaeus, 1758) & $\begin{array}{l}\text { USA. } \\
\text { Massachussetts }\end{array}$ & $\begin{array}{l}\text { Protostome } \\
\text { AToL000306 }\end{array}$ & AY377660 & AY145406 & AY377625 & AY377778 & AF353154 \\
\hline Siphonariidae & Siphonaria pectinata & (Linnaeus, 1758) & Spain, Andalusia & $\begin{array}{l}\text { MCZ } \\
378735\end{array}$ & X91973 & DQ256744 & AY377627 & AY377780 & AF120638 \\
\hline
\end{tabular}

${ }^{*}$ Composite terminal, as Pinnidae sp.

MCZ specimens are accessible at http://mczbase.mcz.harvard.edu/SpecimenSearch.cfm

BivAToL specimens are vouchered at FMNH; see also http://www.bivatol.org/

UF: University of Florida Museum of Natural History

UMASS: University of Massachusetts, Boston. 


\section{${ }^{\star}$ Graphical Abstract (for review)}

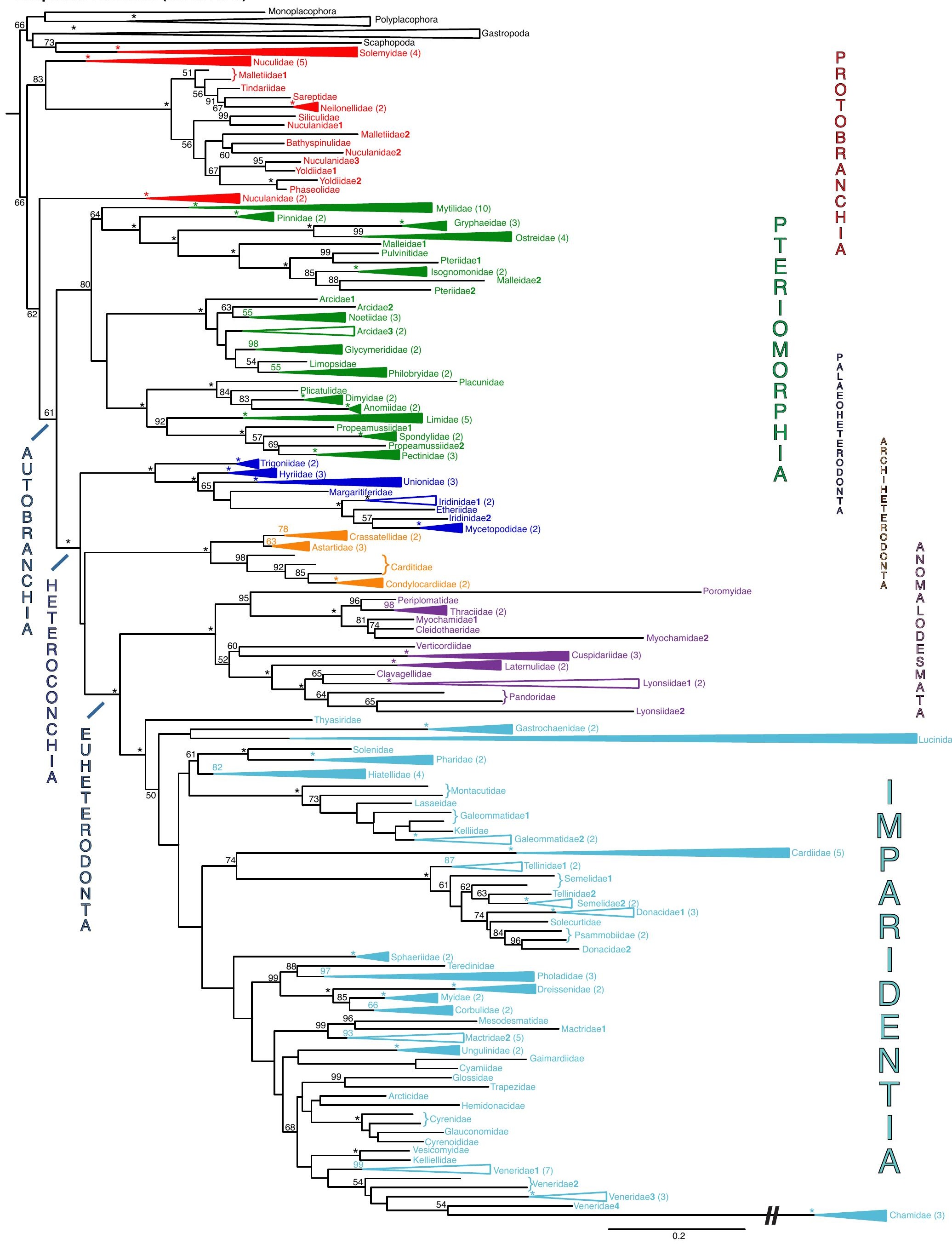

